\title{
The potential of antitranspirants in drought management of arable crops: a review
}

by Mphande, W., Kettlewell, P.S., Grove, I.G. and Farrell, A.D.

Copyright, publisher and additional Information: This is the author accepted manuscript. The final published version (version of record) is available online via Elsevier.

This version is made available under the CC-BY-ND-NC licence:

https://creativecommons.org/licenses/by-nc-nd/4.0/legalcode

Please refer to any applicable terms of use of the publisher

DOI: https://doi.org/10.1016/j.agwat.2020.106143 
1 The potential of antitranspirants in drought management of arable crops: a

2 review.

3 Wiza Mphande ${ }^{\mathrm{a}, \mathrm{c}}$, Peter S. Kettlewella, Ivan G. Grove ${ }^{\mathrm{a}}$ and Aidan D. Farrell ${ }^{\mathrm{b}}$

$4 \quad$ aDrought Mitigation Group, Crop and Environment Sciences Department, Harper

5 Adams University, TF10 8NB, Newport, UK.

$6 \quad$ bDepartment of Life Sciences, The University of the West Indies Trinidad, West

7 Indies.

$8 \quad{ }^{c}$ Corresponding author. Email: wmphande@harper-adams.ac.uk

\section{Abstract}

About $80 \%$ of global farmland is under rain-fed conditions and most of it prone to

11 drought, which limits crop productivity. Due to climate change, drought will

12 become more frequent and severe threatening world food security.

13 Antitranspirants, materials that reduce transpiration, could potentially result in

14 greater food production by realising more of a crop's potential yield during drought. Despite antitranspirants also reducing photosynthesis, research has shown that they can mitigate drought stress resulting in increased grain yield. Although this paper is not restricted to specific years, part of it is a systematic review of 173 original research articles published between 2009 and 2018.Overall, the analysis suggests that interest in the potential of antitranspirants is growing. One major achievement in antitranspirant research during the past decade was establishing the optimal timing of application of the substances, which is linked to reproductive processes most vulnerable to drought. Despite research evidence of the efficacy of antitranspirants in ameliorating drought stress, they are not widely used for commercial arable crop production. However, in fruit horticulture, 
25 products with antitranspirant effects are being used for various non-antitranspirant

26 purposes such as synchronising fruit ripening, enhancement of nutritional quality,

27 protection against sunburn and controlling diseases and insect pests.

28

29

30

31

32

33

34

35

36

37

38

39

40

41

42

43

44

45

46

47

48

49

50 


\subsection{Introduction}

52

53 Future crop productivity and world food security will be undermined by severe and more frequent droughts and other abiotic stresses (IPCC, 2018), and reducing transpiration with antitranspirants (ATs) may have a role in ameliorating drought. About $80 \%$ of the total cropped area globally is under rain-fed agriculture (Huang

57 et al., 2019, supplementary information), and prone to droughts 58 (https://youtu.be/Sy0u8LCZK50, Singh et al., 2017). Under a frequent drought scenario predicted for the future, reducing transpirational water loss will be required to obtain improvements in grain yield. The rapidly increasing world population, projected to reach 9.8 billion by 2050 (United Nations, 2017), will put pressure on food demand. Cereal production must increase by $26 \%$ from 2.8 to data) in order to avert global food insecurity. 
Detailed reviews of drought avoidance and other plant adaptive strategies to water

deficit stress have been dealt with in previous reviews (e.g. Farooq et al., 2009 and Luo, 2010). Also, not discussed here are silicon, and biostimulants like proline and the various compounds extracted from seaweed (such as betaines). These products have drought ameliorative effects which are unrelated to transpiration such as up-regulating flavonoid biosynthesis and antioxidant activities (Ma et al., 2015) and reducing osmotic stress (Ghaffari et al., 2019; Khan et al., 2009).

Thirty-eight years have passed since the last general review on ATs by Solarova et al., (1981). This may in part be due to the negative research conclusion in the late-1970s, which was echoed by Solarova et al., (1981) that ATs were not generally recommended for use in arable crop production. Much of the research on ATs in the past was conducted between 1950 and 1979 (Kettlewell et al., 2010). Researchers at that time found that although ATs improved the water status of plants by reducing the rate of transpiration, the products also reduced the intake of carbon-dioxide $\left(\mathrm{CO}_{2}\right)$ and hence the rate of photosynthesis (Kettlewell et al., 2010). In fact, ATs were found to be less permeable to $\mathrm{CO}_{2}$ than water vapor (Plaut et al., 2004; Woolley, 1967). Because of this, the conclusion made was that ATs were unsuitable for use in crop production except where survival of the plant was at stake, in which case photosynthesis was of secondary importance (Das and Raghavendra, 1979; Davenport et al., 1972). This explains the decline in AT research after the 1970s and why the technique remains largely neglected. However, it is important to note that photosynthesis is partially reduced and not completely stopped by ATs, and that the reduction in carbon assimilation is outweighed by the benefit if the products are applied to protect the most drought sensitive stage (Kettlewell, 2014). Das and Raghavendra (1979) concluded that 
101

102

103

104

105

106

AT products were only economically feasible for specific enterprises such as high value fruit production. Although AT products currently have commercial relevance in fruit horticulture (e.g. for protection against sunburn, synchronising ripening and pest protection), there is no evidence that they are being used for drought amelioration. This suggests that they may still be not be cost-effective for low value crop production systems like arable farming.

\subsection{Antitranspirant classes}

The mode of action of each one of the three classes of ATs and their representative compounds (Table 1) are reviewed below.

\section{Position for Table 1}

\subsection{Research topics between 2009 and 2018}

A decadal overview of AT classes used and research objectives was done using original research articles published between 2009 and 2018. Our sampling of research papers in this decade was for a more quantitative assessment aiming to reveal the trends in research in recent years. Non-drought amelioration uses of ATs were included in the analysis for the purpose of demonstrating the wider range of uses of AT products. Papers were accessed using the search engines Google Scholar and the Harper-Adams University's electronic library system, with links to several databases including BioOne, Web of Science and ScienceDirect which were relevant to this study. A total of 173 peer-reviewed original research papers were collated and analysed on the basis of crop type, AT type and 
research objective (Table 2). The trend of publications shows that research interest in the potential of ATs is increasing.

\section{Position for Table 2}

\subsection{Reflective antitranspirants}

As their name suggests, reflective ATs function on the basis of reflectance to minimise leaf temperature and consequently the transpiration rate (Glenn, 2012). Once reflective ATs have been applied, the foliar characteristics to absorb, reflect and transmit light are altered, modifying leaf temperature and gas exchange variables (Abou-Khaled et al., 1970). Kaolin (an aluminosilicate, $\mathrm{Al}_{4} \mathrm{Si}_{4} \mathrm{O}_{10}(\mathrm{OH})_{8}$, Cantore et al., 2009) is foremost among the reflective ATs being the most studied as the survey of published literature revealed (e.g. between 2009 and 2018, there were 78 original research papers on kaolin versus 18 on the other reflective ATs). Ordinary kaolin, in its crude form, has impurities of titanium dioxide $\left(\mathrm{TiO}_{2}\right)$ and ferric oxide $\left(\mathrm{Fe}_{2} \mathrm{O}_{3}\right)$, but as a particle film technology product, it is upgraded to a highly light reflective, fine grained $(<2 \mu \mathrm{m})$, low-abrasive product of over $99 \%$ purity, after a spreader-sticker is added (Brito et al., 2019; Glenn and Puterka, 2005). Applied to the leaf surface, it forms a whitish film (Boari et al., 2015) by which the optical properties of the target leaf are transformed.

With enhanced reflective properties, particle film kaolin is more effective than unprocessed kaolin in minimising the heat load on leaf surfaces, as more infrared radiation and ultraviolet rays are reflected (Brito et al., 2019; Glenn and Puterka, 2005). Despite reduced transpirational cooling, previous studies reported leaf 
148 temperature reduction (or canopy temperature depression) effect due to kaolin of $149>3{ }^{\circ} \mathrm{C}$ e.g. by $5.6^{\circ} \mathrm{C}$ in walnut (Gharaghani et al., 2018), and between 3 and $4{ }^{\circ} \mathrm{C}$ in 150 Valencia orange - corresponding to a $22-28 \%$ decline in transpiration 151 (Abou-Khaled et al., 1970), similar to $3.8^{\circ} \mathrm{C}$ in snap beans (AbdAllah et al., 2019). 152 Kaolin was effective in reducing transpiration and leaf temperature (by $1.4^{\circ} \mathrm{C}$ ) in 153 field beans (Tworkoski et al., 2002). However, kaolin can have an opposite effect on leaf temperature if the target plant is not under drought stress. In grapes plants sprayed with kaolin, Brillante et al., (2016) observed an increase in leaf temperature of $1.47^{\circ} \mathrm{C}$ in well-watered versus a $1.30^{\circ} \mathrm{C}$ decrease in water-stressed. The increase in leaf temperature under well-watered conditions is attributable to kaolin occluding stomata, reducing the transpirational cooling effect in the process. This means that to reduce the negative effects of high temperature on crop physiology, drought stress is a requisite. This may not be true in all cases as kaolin is widely used to solely protect fruit from sunburn. In mung beans (Vigna radiata $L$ ), water deficit stress was demonstrated as a prerequisite to kaolin application for improved yield (De and Giri, 1978). Kaolin can also cause an increase in leaf temperature under low photosynthetic photon flux density (Brillante et al., 2016) and also lead to reduced photosynthesis (Brito et al., 2019). In apples, (Gindaba and Wand, 2005) observed up to $1.1^{\circ} \mathrm{C}$ increase in leaf temperature. Further, by partially occluding stomata, reflective ATs can also partially contribute to a reduced gas exchange profile of the pores (Boari et al., 2015).

For transpiration to occur, a vapour pressure gradient between the leaf and the surrounding air is necessary (Bloomfield et al., 2019; Medina and Gilbert, 2015). By lowering the leaf heat energy balance, the vapour pressure gradient between 
173 the leaf and the air is narrowed, thereby decreasing the transpiration rate (Kostka and Aquatrols Corporation of America, 2018). Additionally, particle films confer protection to the photosynthetic apparatus, particularly photosystem II reaction centres against excessive irradiance (P.S.O. da Silva et al., 2019; Dinis et al., 2018). This suggests that plants that have been sprayed with particle films can have not only higher but also longer-lasting photosynthesis before initiation of senescence. While reflecting infrared radiation and ultraviolet rays, reflective ATs also reduce the amount of photosynthetically active radiation (PAR) absorbed (Brillante et al., 2016) and hence have a negative effect on photosynthesis. However, depending on the canopy architecture, reflection can result in a positive redistribution of light with an overall enhancement of whole canopy photosynthesis, especially in dense canopies (Brito et al., 2019; Glenn, 2012).

The two calcium-based reflective $\mathrm{ATs}, \mathrm{CaCO}_{3}$ and $\mathrm{CaO}$ have a similar mode of action to kaolin. At the time of this review, there was no known study on arable crops involving these ATs, and only a few on non-arable species (e.g. banana (ElKhawaga, 2013) and grapes (P.S.O. da Silva et al., 2019). This may be explained effects than $\mathrm{CaCO}_{3}$. In 28 days after application (DAA) the luminosity value of maintained reduced leaf temperature and gas exchange variables and higher chlorophyll (P.S.O. da Silva et al., 2019; Paulo Silas Oliveira da Silva et al., 2019). To obtain a complete and equivalent foliar coverage to that of $\mathrm{CaCO}_{3}$, the concentration of $\mathrm{CaO}$ needs to be doubled (e.g. $20 \% \mathrm{w} / \mathrm{v} \mathrm{CaO}$ versus $10 \% \mathrm{w} / \mathrm{v}$ 
duration of efficacy (Paulo Silas Oliveira da Silva et al., 2019). Besides calcium compounds, reflective ATs less researched include any other mineral-based products such as magnesium carbonate $\left(\mathrm{MgCO}_{3}\right.$, Al-Desouki et al., 2009) and magnesium silicate $\left(\mathrm{MgO}_{3} \mathrm{Si}\right.$, Schrader, 2011). One environmental concern with reflective ATs that needs addressing is the effect on non-target organisms as further reviewed in the last section.

\subsection{Metabolic or stomata-closing antitranspirants.}

Metabolic ATs are a group of substances that have hormone or hormone-like effects, inducing partial stomatal closure by acting on guard cells (AbdAllah et al., 2018). Prominent in this class is exogenous abscisic acid (ABA) in its naturallyoccurring bioactive form (S)-cis-ABA (s-ABA) or a commercially available mixture with the synthetic $(R)$-cis-ABA (J. Li et al., 2017). ABA signalling causes an efflux of ions from guard cells, and water by osmosis, leading to flaccidity of the cells with concomitant stomatal closure (Kim et al., 2012; Munemasa et al., 2015). Several studies have reported drought tolerance and yield improvement effects of exogenous ABA e.g. in artichoke (Shinohara and Leskovar, 2014) and wheat (Travaglia et al., 2010; Zhang et al., 2016).

$A B A$ as an $A T$ is perhaps the most prominent product in this group, as chitosan and fulvic acid are not solely ATs but are also used as biostimulants to improve uptake of both major and trace elements - even on crops under well-watered conditions - (Pettit, 2004; Sootahar et al., 2019). Plant biostimulants are substances or micro-organisms that are applied on plants on or in their growth medium to enhance growth by boosting nutrient uptake or tolerance to biotic or abiotic stress (Brown and Saa, 2015). The mechanism of interaction between 
exogenous $A B A$ as an $A T$ and endogenous $A B A$ is not well understood. However,

it is known that benefits from endogenous $A B A$ are short-term and occur only under mild drought stress (Sreenivasulu et al., 2012). This corroborates with the short-lived (less than seven days) effects of exogenous ABA on stomatal closure in wheat (Travaglia et al., 2010). During reproductive-stage drought stress, endogenous ABA may induce premature senescence with undesirable effects such as reproductive organ abortion (Pang et al., 2017); and loss of grain number if drought coincides with meiosis in grain-bearing crops like cereals and pulses (Dolferus et al., 2011; Ji et al., 2011). Applying ABA as an AT during meiosis may therefore negatively affect crop productivity. In commercial fruit horticulture, ABA is used for fruit quality enhancement, particularly of table and wines grapes 234 (Gonzalez et al., 2018).

Closely connected to $A B A$ signalling is the metabolic pathway regulated by chitosan. In field bean plants (Phaseolus vulgaris L.), Iriti et al. (2009) found that a foliar chitosan application led to stomatal closure and a reduction in transpiration. An increase in the endogenous ABA concentration (more than threefold) and that of hydrogen peroxide $\left(\mathrm{H}_{2} \mathrm{O}_{2}\right)$ was also observed one day after spraying. The intrinsic WUE was not significantly improved. Chitosan is known to cause stomatal closure by promoting biosynthesis of $\mathrm{ABA}$, but the mechanism by which this is accomplished is not well understood (Hidangmayum et al., 2019). Although Iriti et al. (2009) did not explain the link between $A B A$ and $\mathrm{H}_{2} \mathrm{O}_{2}$, in faba beans (Vicia faba L.), it is known that ABA signalling downstream induces the production of $\mathrm{H}_{2} \mathrm{O}_{2}$, as a secondary messenger, to cause stomatal closure (Arve et al., 2014). Calcium ions, nitric oxide and reactive oxygen species are among the other secondary messengers in the ABA signalling network (Lee and Luan, 2012). 
248 The other biostimulant-antitranspirant in the metabolic AT class is fulvic acid.

249 Fulvic acid is a by-product of organic matter decomposition that dissolves in both alkaline and acid solutions (Klucakova et al., 2000). It is a variable mixture of both aliphatic and aromatic organic acids, which are similar to humic acids but more reactive (Pettit, 2004). Along with this diverse chemical constitution, fulvic acid has both AT and biostimulant functions. As an AT, the effects of fulvic acid on gas exchange physiology have been studied in a number of crops and genotypes. In maize growing under drought stress (soil moisture at $35 \%$ of field capacity), Anjum et al. (2011) found that fulvic acid applied at the tasselling stage insignificantly increased stomatal conductance by $13 \%$ while transpiration rate, net photosynthesis and WUE were significantly improved, implying that fulvic acid acted as a biostimulant instead. Zhang et al. (2016) found that while exogenous ABA significantly reduced both stomatal conductance and transpiration rate in wheat under mild drought stress, fulvic acid was not effective. Zhang et al. (2016) and Anjum et al. (2011) apparently contradict Xudan (1986), who observed that fulvic acid was effective in reducing stomatal conductance in wheat and improving water potential and grain yield. This discrepancy might be attributed not solely to genotypic and interspecific factors but also to the chemical variability of fulvic acid. Working on wheat, Dunstone et al. (1988) confirmed that although fulvic acid reduced stomatal conductance, its effects were highly variable. In a glasshouse experiment, a reduction in stomatal conductance was recorded only in wellwatered but not in drought stressed plants. Furthermore, while in the four most responsive genotypes the reduction ranged between 15 and $40 \%$, it was only between 1 and $3 \%$ in the least. In addition, for the highly responsive genotypes,

272 the effect was stable in growth cabinets where artificial light was used, but rapidly 
273 decayed under natural light, becoming marginally significant to non-significant

274 within four to seven days. The heterogenous composition of the molecular

275 structure of fulvic acids and other biostimulants, particularly the functional groups,

276 affects their chemical and physico-chemical properties (Bai et al., 2015;

277 Klucakova, 2018) and thus may partly explain the contradictory findings. For, this reason, replicating experiments involving these products is impossible as there is not a single mode of action (Brown and Saa, 2015). A consideration of these findings by different researchers suggests that the mechanism of drought amelioration by fulvic acid may not significantly be mediated by stomatal movement but rather through its biostimulant functionalities. Fulvic acid biostimulant functionalities are its roles or functions for which it is have been found to be more effective or better suited as a biostimulant (e.g. enhancing bioactivity of glutamic oxaloacetic transaminase to improve nutrient uptake in wheat, Zhimang et al., 2001 and increasing gas exchange and carbon assimilation, Anjum et al., 2011, which are opposite effects of an AT).

Besides modifying gas exchange variables, both chitosan and fulvic acid confer drought tolerance through biostimulant functions. By inducing antioxidant activities, they enhance scavenging for reactive oxygen species and promote cellular membrane integrity (Bistgani et al., 2017; Z. Li et al., 2017). In addition to improving the water potential of droughted wheat plants, fulvic acid was found to alleviate the loss of chlorophyll and enhance the uptake of phosphorus by roots (Xudan, 1986). Z. Li et al. (2017) found that chitosan not only improved water balance in droughted white clover but also up-regulated antioxidant activity and chlorophyll content. 
297 The short-lived effects of metabolic ATs and that the use of chitosan and fulvic acid is not restricted to drought stress conditions imply that concerns that these ATs may hinder crop growth and productivity in an event of improved soil moisture status (e.g. following rainfall) are unnecessary.

Phenyl mercuric acetate (PMA), a popular subject of metabolic AT research in the past (Sinclair et al., 1975), was found to be toxic (Das and Raghavendra, 1979). It disappeared from AT research but was still used as a fungicide before being banned in some countries (Nandi, 1985). India is apparently the only country where the use of PMA as an AT (e.g. Pandey et al., 2017 and Kumar et al., 2018) remains legal.

Another compound with an ABA-related mechanism is pyrabactin, a synthetic growth inhibitor with a sulphonamide functional group (Cao et al., 2013). Though not among the popularly known ATs, it has a mode of action similar to ABA and is its agonist but not its structural analogue (Fan et al., 2015). In peas (Pisum sativum L.), Puli and Raghavendra (2012) found that pyrabactin had similar effects to ABA on stomatal closure. Stomatal apertures decreased by a larger percentage in plants where pyrabactin and ABA were used together, suggesting a synergistic mechanism. Nevertheless, pyrabactin may not play a significant role in drought more e.g. Park et al., 2009, Yu et al., 2017 and Han et al., 2019) were conducted in the field or on well established crops to provide conclusive evidence of the potential of pyrabactin as an AT. 
The currently available film-forming ATs are mostly water-emulsifiable organic polymers that form films after a spray application has dried (Moftah and Alhumaid, 2005). The films act as a physical barrier over stomata by which transpirational water loss is reduced.

Di-1-p-menthene (pinolene) is the oldest film-forming AT with one of the earliest references being Williamson (1963). Under glasshouse conditions, (Faralli et al., 2016) compared the drought ameliorative effects of di-1-p-menthene and poly-1-pmenthene on oil seed rape. Both compounds significantly reduced gas exchange, however, di-1-p-menthene was not only more effective in suppressing stomatal conductance (by $50 \%$ against $11 \%$ ) but also sustained the effect for a longer period (>14 days versus < nine days). The yield component results were consistent with the stomatal conductance readings, with di-1-p-menthene having higher values for number of pods per plant and seed biomass, suggesting that the negative effect on $\mathrm{CO}_{2}$ fixation was compensated for by increased WUE. The efficacy of di-1-p-menthene in suppressing gas exchange has also been demonstrated on horticultural species, especially grapes, and not only for foliar but also bunch transpiration (Fahey and Rogiers, 2018; Vaio et al., 2019). In an AT comparative study on droughted grapes, di-1-p-menthene was found to depress photosynthesis and intrinsic WUE while kaolin enhanced these variables (Brillante et al., 2016). This suggests that different classes of AT do not induce similar physiological responses.

One group of compounds in this class, paraffinic hydrocarbon waxes - Folicote (Francini et al., 2011; Fuehring, 1973) was effective in suppressing gas exchange 
variables and increasing yield (e.g. between 11 and 17\% in maize (Fuehring and

347 Finkner, 1983) and five to $17 \%$ in sorghum (Fuehring, 1973). However, paraffinic hydrocarbon waxes do not feature in recent AT research. Other less important compounds, on which limited research has been published include vegetable oils and acrylic polymers. The former may become important in future as they are not only cheaper (Granger and Trager, 2002) but more readily available than synthetic products.

A film-forming AT end-user advantage over other AT classes is the less frequent application, typically once for 30 days for an acrylic polymer in a glasshouse (Plaut et al., 2004), though for poly-1-p-menthene it was less than nine days in the OSR study above. In comparison, weathering agents can significantly reduce the foliar coverage and efficacy of reflective ATs to less than half a month (e.g. $\mathrm{CaCO}_{3}$ (P.S.O. da Silva et al., 2019). As for metabolic ATs, their effects generally last for a few days (Travaglia et al., 2010), being controlled by the plant biochemistry since they are absorbed unlike the other ATs.

Although the use of ATs is valid only under drought stress conditions, in an event of improved soil moisture status due to rainfall, it would be desirable to remove them from the plant surface, particularly film antitranspirants. The importance of removing film antitranspirants in an event of unexpected rains is one research gap that needs pursuing. However, in the case of cereal stands the impact of film antitranspirants will reduce over time as new leaves emerge and take their place at the top of the canopy. This is particularly relevant in this case as it is these later grain. 
370 Finally, one other concern during early AT research that is more relevant to film-

371 forming types was the effect on leaf temperature. However, the review by Gale and Hagan (1966) shows that an intersection of high solar radiation and very low wind speed was required to significantly increase leaf temperature due to reduced

374 transpiration. In fact, a $30 \%$ reduction of transpiration attributed to ATs was found

375 to have no significant effect on leaf temperature (Gale and Poljakoff-Mayber, 1965). However due to global warming, the use of reflective ATs may play a more important role in drought stress mitigation. climate change (IPCC, 2018). Elevated $\mathrm{CO}_{2}$ reduces transpiration rate (e.g. up to $30 \%$ in carnation plants), however there is no consensus due to environmental and interspecific differences (Xu et al., 2016). Drought, one of the consequences of climate change, reduces plant nutrient uptake (Nawaz et al., 2012). There is currently limited information on the interaction of antitranspirants, elevated $\mathrm{CO}_{2}$ and drought. One particular source is del Amor et al. (2010) who tested the effects on pepper. They showed that under elevated $\mathrm{CO}_{2}(2000 \mathrm{ppm})$ and drought, stomatal conductance was higher with antitranspirant (di-1-p-menthene) application four and eight days after spraying (when measurements were taken), although the difference was not significant. The corresponding $\mathrm{CO}_{2}$ assimilation effect was inconsistent being significantly higher in antitranspirant treated plants four days after spraying, and becoming non-significant at eight days after spraying. The response of transpiration rate was consistent with stomatal conductance. Interestingly, benefits of elevated $\mathrm{CO}_{2}$ were only attainable under 
well irrigated conditions, with no significant difference between antitranspirant treated and untreated plants. These findings suggest that elevated $\mathrm{CO}_{2}$ may not be as potent as di-1-p-menthene in suppressing gas exchange. Further, this may eliminate concerns of reduced transpiration-driven nutrient uptake by mass flow induced by elevated $\mathrm{CO}_{2}$ and other factors that suppress transpiration (Mcgrath and Lobell, 2013). However, further research is needed to make well established conclusions on interactions between drought, ATs and elevated $\mathrm{CO}_{2}$ and how these affect plant nutrition and growth of various crops. Other impacts of global climate change will reduce the availability of soil moisture in some cases and affect transpirational processes. This may make dynamic drought management become more important.

\subsection{The basis for timing of antitranspirant application}

407

Drought has varying effects on crop performance depending on its timing in relation to crop growth stage (GS). In cereals, drought at any time before the end of grain filling will affect grain yield. However, the worst is terminal drought (soil moisture deficit during a crop's reproductive development stages) as it has a grain yield limiting effect by reducing grain number (Saradadevi et al., 2017). Reproductive processes such as meiosis and microgametogenesis that occur during booting are the most susceptible to abiotic stresses such as drought (Barber et al., 2015). There is a strong correlation between grain number per ear and grain yield (Liu et al., 2015). In rice Kato et al. (2008), found that a mild

417 drought stress at meiosis triggered secondary rachis and spikelet abortion per panicle of $70 \%$ and $45 \%$ respectively while drought at panicle initiation did not 
420 Faralli et al. (2016) showed that improving the water status of drought-stressed 421 plants with film-forming AT during the reproductive stage was positively correlated with not only an increase in the number of pods per plant but also the seed yield. The processes of microsporogenesis (involving meiosis in pollen mother cells) and microgametogenesis (development of microspores into mature pollen grains) are known to be more sensitive to water stress than their female counterparts (De Storme and Geelen, 2014; Jager et al., 2008). Sensitivity to drought is most critical at the young microspore stage during microgametogenesis (Dolferus et al., 2011; Ji et al., 2010). However, Barber et al. (2015) argued that due to the influence of environmental and genotypic aspects, it was not possible to associate the most sensitive development processes with any one particular GS. Nevertheless, it is considered to be during booting; and in wheat there is evidence that it occurs between GS41 and GS43 (Alghabari et al., 2013; Barber et al., 2015). While it is not until near anthesis that the male gametophyte begins to accumulate starch grains, the process begins earlier in the female gametophyte ( $\mathrm{Ji}$ et al., 2010; Raghavan, 1988), implying that in early development, pollen grains accumulate less carbohydrate reserves than ovaries. This could partly explain the higher vulnerability of pollen grains to abiotic stress during this period compared to ovaries. It may be for the same reason that most of the abiotic stress research on reproductive performance has focussed on the male gametophyte. A study by Onyemaobi et al. (2017) involving reciprocal crosses between well-watered and water stressed wheat plants provides evidence. Onyemaobi et al. (2017) found that only four out of 13 genotypes showed the female gametophyte to be significantly more sensitive to drought than the male gametophyte. Nearly $70 \%$ of cultivars studied showed the male gametophyte to be more susceptible to water 
445 deficit stress than the female counterpart. It is the susceptibility of these reproductive processes coinciding with terminal drought that forms the foundation for the timing of AT application.

\subsection{Re-evaluating antitranspirants}

449

450

With reproductive processes identified as the most sensitive to drought, AT application timed to protect these stages is expected to result in the highest possible benefits to grain yield under water stress. One of the important developments in AT research in the recent past has been the identification of the most critical stage at which to apply ATs in order to optimise their usefulness under drought conditions. Overall, early AT researchers overlooked the role of plant GS in modulating the efficacy of ATs leading to the erroneous conclusion in the 1970 s that AT use was only recommended if plant survival was at stake due to the negative effects on photosynthesis. In fact, even in the 1970's, the necessity of studying the effects of timing of AT application was mentioned by Davenport et al. (1972).

461 There are two notable exceptions to early AT researchers overlooking the importance of development stage. Fuehring (1973) researched the effects of rate of application of three ATs (metabolic - atrazine and PMA and film-formingFolicote) and of irrigation frequency on the transpiration and yield performance of sorghum. In addition, he tested the effects of timing of application of PMA sprayed on three sets of plants at eight days before booting, 20 days after booting and a third set receiving double sprays - once on each of these days- and the unsprayed control plants. He found that the effects on grain yield of the lower rates of 
atrazine and PMA, and the higher rate of Folicote were not significantly different from the unsprayed control plants. However, the higher rates of atrazine and PMA and lower rate of Folicote increased yield. Concerning timing of PMA application, spraying at eight days before booting resulted in significantly the highest yield response followed by double sprays. This research showed that not only the type of compound but also the rate of AT application modulates agronomic efficacy.

Later, Patil and De (1978) conducted a similar study but on oilseed rape and using Mobileaf (film-forming AT), kaolin (reflective AT) and PMA (metabolic AT). All ATs improved grain yield above the unsprayed and droughted plants. PMA applications were repeated, at the initiation of flowering and during pod development. Since the treatments at these different GSs involved the same plants, there was no basis for a comparative analysis. Nevertheless, it is noteworthy to state that they focused on the most drought-sensitive stages.

Recent research has been more robust in terms of understanding timing effects of AT application. Results have shown that despite reducing photosynthesis, ATs applied within specific plant GS can improve the performance of crops growing under water stress. Kettlewell et al. (2010) found that di-1-p-menthene (filmforming AT) improved grain yield of droughted wheat if the reproductive stages most sensitive to drought stress were protected. They tested the timing response of winter wheat to di-1-p-menthene application at five GSs (GS described by Zadoks et al. (1974) as GS37, GS39, GS45, GS55 and GS69). Their results revealed that di-1-p-menthene was most beneficial to yield improvement if applied at GS37 and GS39, unlike at GS45. On the other hand, much later applications at GS55 and GS69 were counterproductive in that they reduced crop yield - thus being corroborative of the 1970s research conclusion. Further, the AT was also 
494 found to reduce yield if soil water deficit was not high. Soil moisture deficit was earlier found as a precondition for kaolin application to obtain yield improvement in mung beans De and Giri (1978). These findings agree with the analysis presented by Gale and Hagan (1966). The importance of the shoot/root ratio theory as presented by Gale and Hagan (1966) suggests that antitranspirants would be more effective for plants with high values (i.e. higher shoot-to-root biomass, due to lower actual-to-potential evapotranspiration ratio under well-watered conditions, below 0.9). Their argument implies that antitranspirants should not be used where the shoot/root ratio is lower as evapotranspiration is higher, except in an event of abiotic stress such as reduced mineral uptake from the soil (e.g. due to drought) that leads to the breakdown of the photosynthetic machinery (chlorosis). In such a situation antitranspirants would have a reduced inhibitory effect on photosynthesis as the mesophyll resistance to $\mathrm{CO}_{2}$ conductance is high. This analysis indicates that shallow-rooted plants, being more prone to drought stress, would need AT application before deep-rooted ones. Taken together, the works by De and Giri (1978) and Kettlewell et al. (2010) demonstrated that not only drought stress was required as a precondition for AT application but the crop growth stage most sensitive to water stress must be protected for ATs to improve crop yield.

512 As discussed by Barber et al. (2015), the period of pollen development can last several days within a spike and much longer in a crop due to asynchrony between the male and female gametophytes. For this reason, reproductive stages sensitive to drought damage have a wider span in a crop and are not limited to a single GS.

516 Refining limits within which farmers may apply AT to maximise benefits is critical and therefore requires further research. Nevertheless, Kettlewell et al. (2010) 
established that crop development stages most sensitive to water stress dictate timing of di-1-p-menthene application for optimum benefits.

520 Following the work of Kettlewell et al. (2010) on the role of crop development stage, other researchers have found corroborative evidence. Kettlewell and Holloway (2010) applied di-1-p-menthene at the boots swollen stage, GS45, and found that it improved yield of droughted wheat by as much as $42 \%$ compared with droughted-and-unsprayed plants. In a separate study involving two water treatments and two GS, Abdullah et al. (2015) observed 30\% more wheat grain yield in droughted plants treated with di-1-p-menthene at the booting stage than in the droughted but unsprayed plants, while application at anthesis had no significant effect on yield. Recently, Faralli et al. (2017) reported $22 \%$ yield improvement in oil seed rape plants treated with film-forming AT as floral initiation was taking place but with no improvement from applications at initiation of seed development. These findings during the last decade are a refutation of earlier research in terms of ameliorative effects of ATs on droughted crops.

533 Though in part, the mechanisms by which metabolic and reflective ATs ameliorate drought are better understood than those of film-forming types. However, discrepancies between researchers indicate the need for more research. As Gale and Hagan (1966) indicated, this may be attributed to ambient, edaphic and plant factors such as wind speed, soil water status and turgor of cells, respectively, prevailing at and after AT application - necessitating the need for researchers to provide sufficient details in these areas. In spite of our knowledge that di-1-pmenthene applied at the right GS and under drought conditions improves grain 541 yield, the underlying physiological mechanisms by which this compound 542 ameliorates drought beyond blockage of stomata are unknown. A study by 
543 Weerasinghe et al. (2016) attributed wheat grain yield improvement under drought 544 conditions using di-1-p-menthene to increasing of pollen viability, via increased

545 plant water conservation. Nevertheless, the discovery of this relationship was only 546 correlative and not a conclusive cause-and-effect one. Thus, the underlying 547 mechanisms by which di-1-p-menthene improves reproductive development - be 548 they hormonal or metabolic or otherwise - are yet to be established. In a drought 549 stressed oil seed rape study by Faralli et al. (2016), a four-fold decrease in endogenous ABA concentration following an application of di-1-p-menthene was

551 correlated with a $17 \%$ yield improvement. This suggests that the drought 552 amelioration effects of di-1-p-menthene may be related to increased catabolism and/or reduced biosynthesis of $\mathrm{ABA}$. Increased $\mathrm{ABA}$ concentration is known to repress cell wall invertase $(\mathrm{CWIN})$ via down-regulation of genes controlling the synthesis of this enzyme (Ji et al., 2010; Koonjul et al., 2005). The significance of CWIN to reproductive development lies in their hydrolysis of sucrose into glucose and fructose required by anthers and ovaries (Braun et al., 2014; Ruan et al., 2010). Researching the effects of ATs on ABA signalling with respect to CWIN is therefore required. Knowledge of mechanisms, if established, could further feed into developing relevant plant breeding and agronomic management strategies for improving WUE and crop production.

\subsection{Challenges in using antitranspirants and other research gaps}

There are other research gaps in the use of ATs that need addressing besides

565 those identified above and in the conclusion. This review has shown that the effects of ATs on crop development are modulated by prevailing environmental conditions and intraspecific and interspecific factors. This accounts for apparently 
contradictory findings by different researchers, hence the need for thorough description of experimental conditions and materials used. The use of biostimulant ATs such as fulvic acid will be particularly necessary due to their heterogenous

571 nature. The type of AT used in research also modulates plant response.

572 Concerning the effect on leaf temperature, Gale and Hagan (1966) downplayed 573 the risk of overheating due to AT use (Section 3.3). However, global warming is 574 likely to increase the risk of heat stress. This may see film-forming ATs play a minor role than the reflective types that attenuate solar radiation, thereby reducing 576 the heat load on the leaf.

577 Due to suppressing both transpiration and photosynthesis, ATs reduce not only 578 the uptake of minerals from the soil but also carbon assimilation. The negative 579 effect can be minimised by selecting appropriate ATs for a given drought scenario. 580 Metabolic ATs would be ideal in situations where a dry spell which coincides with 581 the most drought-sensitive crop growth stage is expected, while film-forming types would suit prolonged drought events as they have longer-lasting effects (30 to 40 days, Plaut et al., 2004). Nevertheless, finding a product that is more permeable to

$584 \mathrm{CO}_{2}$ than water vapour has been a long standing AT challenge yet to be 585 addressed. Product research is therefore needed to find suitable ATs. Further, 586 ATs may not be used as a sole drought mitigation technique. However, most if not 587 all current research focuses on ATs in isolation. An integrated approach is 588 required, for example, De et al. (1983) demonstrated reduced irrigation 589 requirement in wheat by using combinations of rice stubble and kaolin. Agarwal 590 (1979) obtained the highest barley yield under a combined stubble mulch-and591 kaolin treatment. 
592 The environmental risks associated with the use of the three most popular ATs, 593 ABA, di-1-p-methene and kaolin are likely very low. ABA can be extracted from 594 plants, obtained through microbial fermentation or synthesised (Shi et al., 2017), 595 while di-1-p-methene is extracted from pine resin (Francini et al., 2011). Kaolin, an 596 aluminosilicate, $\mathrm{Al}_{4} \mathrm{Si}_{4} \mathrm{O}_{10}(\mathrm{OH})_{8}$, is obtained from clay (Cantore et al. 2009). 597 However, kaolin is also used to control insect pests, and studies have 598 demonstrated that it is effective (Table 2) against some studied species. 599 Unfortunately, almost all papers reviewed in this article focussed on plant 600 response to ATs, neglecting the potential negative effects on the environment. 601 One exception is Pascual et al., 2010 who showed that while kaolin significantly reduced the incidence of fruit fly (Bactrocera oleae) and black scale (Saissetia oleae), pests of olives, the AT also caused mortality of their natural enemies (e.g. coccinellids or ladybird beetles: Scymnus mediterraneus and Stethorus punctillum, among other families of natural enemies). Earlier, Marko et al. (2008) established that severity of infestation with a number of apple pests (e.g. leaf miner moth and woolly apple aphid) was linked to the use of kaolin. The AT was toxic not only to pests but also their natural enemies (e.g. spiders and common black ants). More research is therefore required to establish off-target effects of other ATs, particularly in this class and in other crops, and how the products can be made safe.

Lack of cost-benefit analysis: Clearer, evidence-based messages on the economic feasibility of using ATs in crops production, especially in arable farming, are needed to help prospective adopters make firm decisions. However, the number of research papers with information on the cost-benefit analysis of using ATs in crop production is meagre (e.g. Kettlewell, 2011 and Brahma et al., 2007). This is not 
617 surprising since yield improvement has been the primary focus of most 618 researchers. Yield loss due to drought needs to be quantified and valued; and the 619 yield benefit due to AT application demonstrated in monetary terms. Lack of 620 thorough, in-depth analyses on the cost-effectiveness of ATs in most crops may 621 partly be blamed for the erratic response of crop producers in the adoption of ATs 622 as a drought mitigation option in arable farming. This might also have stifled research in novel products that could be cheaper.

624 An examination of research findings in Table 2 shows that there has been a 625 number of studies on nutritional aspects of fruit, particularly involving $A B A$ and kaolin ATs. Except for two studies on arable crops, the rest of the research on nutritional effects of ATs were on horticultural crops. This may be attributed to the fact that most of the studies involving AT products have been on horticulture (Table 2).

\subsection{Conclusion and future prospects}

632 The agronomic benefits of ATs have been highlighted in this review. ATs improve 633 yield, conserve irrigation water and also reduce disease and insect pest 634 incidences. The physiological mechanisms by which metabolic and reflective ATs ameliorate drought have been described but exactly how they affect reproductive processes is still unknown. Similarly, although timing of AT application was studied using the film-forming product, di-1-p-menthene, the mode of action of this class of

638 ATs is yet to be established. The discovery of the role of crop GS in modulating 639 AT efficacy in wheat by Kettlewell et al. (2010) has been a major research 
640

641

642

643

644

645

646

647

648

649

650

651

652

653

654

655

656

657

658

659

660

661

662

breakthrough of the last decade. This might be the reason behind the increasing interest in AT research besides the threat of increasing frequency of droughts.

As the findings of Kettlewell et al. (2010) were based on a film-forming AT, there is need for a comparative study involving all the three classes to determine the most effective types. It would also be interesting to examine interspecific responses to the AT classes. Discrepancies in plant response suggest that species, genotype, environment, chemical nature and rate of AT applied further modulate the efficacy of ATs. In wheat and oil seed rape, film-forming di-1-p-menthene has shown consistent positive results in different growth environments. Further research opportunities include understanding possible interaction between ATs and heat stress, testing the efficacy of vegetable oils and integrating ATs with other drought management techniques (e.g. mulching or cover crops). The broader environmental impacts of different types of AT must also be considered. Finally, one of the challenges against achieving world food security ahead of 2050 is not just finding effective drought amelioration techniques but also increasing the knowledge and accessibility to the end users of the technologies. ATs are yet to enter drought amelioration in arable crop production, despite research providing empirical evidence of agronomic benefits. ATs may still be too expensive for use in low value crop production systems hence the need to find cheaper alternatives. Increasing frequency and intensity of droughts and the associated crop failure may stimulate farmers' adoption of ATs for a role in arable crop production. 
673 Table 1: Examples of the main antitranspirant compounds and their modes of 674 action in the surveyed literature between 2009 and 2019.

\begin{tabular}{|c|c|c|}
\hline $\begin{array}{l}\text { Antitranspirant } \\
\text { classes }\end{array}$ & Compounds & References \\
\hline \multirow{3}{*}{ Metabolic } & s-ABA & Park et al. 2016 \\
\hline & $\begin{array}{l}\text { Chitosan (poly (D- } \\
\text { glucosamine)) }\end{array}$ & $\begin{array}{l}\text { Li, Zhang, et al. 2017; } \\
\text { Rieger et al. } 2016\end{array}$ \\
\hline & Fulvic acid & Zhang et al. 2016 \\
\hline \multirow{3}{*}{ Reflective } & Aluminosilicate (kaolin) & Cantore et al. 2009 \\
\hline & $\begin{array}{l}\text { Calcium carbonate } \\
\left(\mathrm{CaCO}_{3}\right)\end{array}$ & da Silva et al. 2019 \\
\hline & Calcium oxide (CaO) & da Silva et al. 2019 \\
\hline
\end{tabular}




\begin{tabular}{|l|l|l|}
\hline \multirow{4}{*}{ Film-forming } & di-1-p-menthene & AbdAllah et al. (2019) \\
\cline { 2 - 3 } & poly-1-p-menthene & Faralli et al. (2016) \\
\cline { 2 - 3 } & Acrylic polymers & $\begin{array}{l}\text { AgroBest Australia } \\
(2017)\end{array}$ \\
\hline
\end{tabular}

675

676

677

678

679 
Table 2: Summary of antitranspirant research based on 173 peer review articles published between 2009 and 2018.

\begin{tabular}{|c|c|c|c|c|c|c|}
\hline Year & $\begin{array}{l}\text { Antitranspirant } \\
\text { class }\end{array}$ & $\begin{array}{l}\text { Antitranspirant } \\
\text { product }\end{array}$ & $\begin{array}{l}\text { Research } \\
\text { area/objective }\end{array}$ & $\begin{array}{l}\text { Crop/plant } \\
\text { species }\end{array}$ & $\begin{array}{l}\text { Some of the reported effects on } \\
\text { crop/plant performance }\end{array}$ & Citation \\
\hline 2009 & Reflective & Kaolin & $\begin{array}{l}\text { Drought and heat } \\
\text { stress }\end{array}$ & Tomato & $\begin{array}{l}\text { Reduced drought and heat stress } \\
\text { and improved marketable yield by } \\
21 \%\end{array}$ & $\begin{array}{l}\text { Cantore et al., } \\
2009\end{array}$ \\
\hline 2009 & Reflective & Kaolin & $\begin{array}{l}\text { Heat stress } \\
\text { management }\end{array}$ & Apple & $\begin{array}{l}\text { Reduced heat stress, increased } \\
\text { carbon fixation and fruit size }\end{array}$ & Glenn, 2009 \\
\hline 2010 & Reflective & Kaolin & $\begin{array}{l}\text { Fruit protection } \\
\text { from sunburn }\end{array}$ & Apple & $\begin{array}{l}\text { Increased light reflectance and leaf } \\
\text { expansion, reduced sunburn, } \\
\text { increased fruit weight and yield }\end{array}$ & Aly et al., 2010 \\
\hline 2010 & Reflective & Kaolin & Water stress & Apple & $\begin{array}{l}\text { Increased photosynthesis, reduced } \\
\text { WUE }\end{array}$ & Glenn, 2010 \\
\hline 2010 & Reflective & Kaolin & $\begin{array}{l}\text { Insect pest } \\
\text { control }\end{array}$ & Olives & $\begin{array}{l}\text { Significant mortality of pests } \\
\text { Bactrocera oleae and Saissetia } \\
\text { oleae and natural enemies (e.g. } \\
\text { Scymnus mediterraneus). }\end{array}$ & $\begin{array}{l}\text { Pascual et al., } \\
2010\end{array}$ \\
\hline 2010 & Reflective & Kaolin & $\begin{array}{l}\text { Insect pest } \\
\text { control }\end{array}$ & Cotton & $\begin{array}{l}\text { Reduced oviposition and egg } \\
\text { number of bollworms, Helicoverpa } \\
\text { armigera }\end{array}$ & Alavo et al., 2010 \\
\hline 2010 & Reflective & Kaolin & $\begin{array}{l}\text { Physiological } \\
\text { responses }\end{array}$ & Grapes & $\begin{array}{l}\text { Reduced leaf temperature and } \\
\text { stomatal conductance but } \\
\text { increased leaf water potential } \\
\text { under well-watered conditions }\end{array}$ & $\begin{array}{l}\text { Michael Glenn et } \\
\text { al., } 2010\end{array}$ \\
\hline 2010 & Reflective & Kaolin & Drought stress & Olives & $\begin{array}{l}\text { Maintained plant water status, } \\
\text { increased canopy biomass, did not } \\
\text { improve chlorophyll content and } \\
\text { fruit yield }\end{array}$ & $\begin{array}{l}\text { Roussos et al., } \\
2010\end{array}$ \\
\hline 2010 & Reflective & Kaolin & $\begin{array}{l}\text { Protection from } \\
\text { sunburn }\end{array}$ & Pomegranate & $\begin{array}{l}\text { Reduced sunburn damage, no } \\
\text { effect on phenolic compounds and } \\
\text { antioxidant activity }\end{array}$ & $\begin{array}{l}\text { Weerakkody et al., } \\
2010\end{array}$ \\
\hline 2011 & Reflective & Kaolin & Insect (Medfly) & Nectarines and & Decreased landing of the pest and & D'Aquino \\
\hline
\end{tabular}




\begin{tabular}{|c|c|c|c|c|c|c|}
\hline & & & control & peaches & fruit damage & 2011 \\
\hline 2012 & Reflective & Kaolin & Drought stress & Olives & $\begin{array}{l}\text { Increased photosynthesis, plant } \\
\text { water content, leaf tissue density } \\
\text { and reduced leaf temperature }\end{array}$ & Denaxa et al., 2012 \\
\hline 2012 & Reflective & Kaolin & Drought stress & Tomato & $\begin{array}{l}\text { Improved WUE (by } 43 \% \text { ) and } \\
\text { increased total biomass and } \\
\text { economic yield }\end{array}$ & Lukic et al., 2012 \\
\hline 2012 & Reflective & $\begin{array}{l}\text { Kaolin plus deficit } \\
\text { irrigation }\end{array}$ & $\begin{array}{l}\text { Irrigation } \\
\text { management }\end{array}$ & Grapes & $\begin{array}{l}\text { Increased terpene alcohols and } \\
\text { anthocyanins, negligible effect on } \\
\text { volatile compounds }\end{array}$ & Song et al., 2012 \\
\hline 2012 & Reflective & $\begin{array}{l}\text { Kaolin, calcium } \\
\text { carbonate }\end{array}$ & $\begin{array}{l}\text { Control of cherry } \\
\text { fruit fly }\end{array}$ & Sweet cherry & $\begin{array}{l}\text { Kaolin more effective than calcium } \\
\text { carbonate in decreasing landing } \\
\text { and oviposition and also with } \\
\text { higher mortality rates }\end{array}$ & Yee, 2012 \\
\hline 2012 & Reflective & $\begin{array}{l}\text { Kaolin, } \\
\text { magnesium } \\
\text { carbonate }\end{array}$ & Drought stress & Jatropha & $\begin{array}{l}\text { Increased relative water content, } \\
\text { reduced osmotic pressure and } \\
\text { carbohydrate content }\end{array}$ & Khalil et al., 2012 \\
\hline 2012 & Reflective & Kaolin & $\begin{array}{l}\text { Irrigation } \\
\text { management }\end{array}$ & Strawberry & $\begin{array}{l}\text { Reduced irrigation frequency, } \\
\text { saved } 20 \% \text { of water required, } \\
\text { increased fruit weight }\end{array}$ & Santos et al., 2012 \\
\hline 2013 & Reflective & Kaolin & $\begin{array}{l}\text { Drought and heat } \\
\text { stress }\end{array}$ & Mango & $\begin{array}{l}\text { Reduced irradiance and leaf } \\
\text { temperature and improved stomata } \\
\text { conductance and photosynthesis. } \\
\text { Increased fruit number and yield by } \\
41 \text { and } 44 \% \text {, respectively }\end{array}$ & $\begin{array}{l}\text { Chamchaiyaporn et } \\
\text { al., } 2013\end{array}$ \\
\hline 2013 & Reflective & $\begin{array}{l}\text { Kaolin, } \\
\text { magnesium } \\
\text { carbonate }\end{array}$ & Drought stress & Wheat & $\begin{array}{l}\text { Improved photosynthetic pigments, } \\
\text { increased yield }\end{array}$ & Desoky et al., 2013 \\
\hline 2013 & Reflective & Kaolin & Aphid control & Wheat & $\begin{array}{l}\text { Reduced damage, improved } \\
\text { biomass and grain yields }\end{array}$ & Nateghi et al., 2013 \\
\hline 2013 & Reflective & Kaolin & Drought stress & Soyabeans & $\begin{array}{l}\text { Increased yield components, } \\
\text { biomass and grain yield }\end{array}$ & Javan et al., 2013 \\
\hline
\end{tabular}




\begin{tabular}{|c|c|c|c|c|c|c|}
\hline 2013 & Reflective & Kaolin & $\begin{array}{l}\text { Boll weevil } \\
\text { (Anthonomus } \\
\text { grandis) control }\end{array}$ & Cotton & $\begin{array}{l}\text { Reduced oviposition and boll } \\
\text { damage }\end{array}$ & $\begin{array}{l}\text { Silva and Ramalho, } \\
2013\end{array}$ \\
\hline 2013 & Reflective & Kaolin & Drought stress & Pistachio & $\begin{array}{l}\text { Increased fresh weight and soluble } \\
\text { solids, reduced early nut splitting }\end{array}$ & Azizi et al., 2013 \\
\hline 2013 & Reflective & $\begin{array}{l}\text { Kaolin and } \\
\text { calcium } \\
\text { carbonate }\end{array}$ & Drought stress & Banana & $\begin{array}{l}\text { Reduced irrigation frequency, } \\
\text { improved crop productivity }\end{array}$ & El-Khawaga, 2013 \\
\hline 2013 & Reflective & $\begin{array}{l}\text { Calcium } \\
\text { carbonate }\end{array}$ & $\begin{array}{l}\text { Fruit protection } \\
\text { from sunburn }\end{array}$ & Grapes & $\begin{array}{l}\text { Chlorophyll and carotenoid } \\
\text { enhancement, berry setting and } \\
\text { yield improvement }\end{array}$ & Ahmed et al., 2013 \\
\hline 2013 & Reflective & $\begin{array}{l}\text { Calcium } \\
\text { carbonate }\end{array}$ & $\begin{array}{l}\text { Control of potato } \\
\text { psyllid } \\
\text { (Bactericera } \\
\text { cockerelli) }\end{array}$ & Irish potatoes & $\begin{array}{l}\text { Reduced oviposition, no effect on } \\
\text { mortality }\end{array}$ & Prager et al., 2013 \\
\hline 2013 & Reflective & Kaolin & Drought stress & Grapes & $\begin{array}{l}\text { Reduced stomatal conductance } \\
\text { and temperature, increased } \\
\text { anthocyanin and phenolics content } \\
\text { and berry fresh weight }\end{array}$ & $\begin{array}{l}\text { Shellie and King, } \\
2013\end{array}$ \\
\hline 2014 & Reflective & Kaolin & $\begin{array}{l}\text { Insect pest and } \\
\text { disease control }\end{array}$ & Wheat & $\begin{array}{l}\text { Decreased reproduction of beetle, } \\
\text { Rhyzopertha dominica, reduced } \\
\text { multiplication of yeast moulds }\end{array}$ & $\begin{array}{l}\text { Campolo et al., } \\
2014\end{array}$ \\
\hline 2014 & Reflective & $\begin{array}{l}\text { Kaolin plus other } \\
\text { materials }\end{array}$ & Drought stress & Wheat & $\begin{array}{l}\text { Improved yield components and } \\
\text { yield }\end{array}$ & Patil et al., 2014 \\
\hline 2014 & Reflective & Kaolin & Heat stress & Grapes & $\begin{array}{l}\text { Increased photosynthesis, } \\
\text { transpiration, total soluble solids, } \\
\text { berry weight, diameter and } \\
\text { improved yield by } 44 \% \text {. }\end{array}$ & $\begin{array}{l}\text { Tepkaew et al., } \\
2014\end{array}$ \\
\hline 2015 & Reflective & Kaolin & $\begin{array}{l}\text { Fruit quality } \\
\text { enhancement }\end{array}$ & Grapes & $\begin{array}{l}\text { Effective in reducing leaf } \\
\text { temperature through reflectance, } \\
\text { did not significantly decrease gas } \\
\text { exchange variables, reduced fruit }\end{array}$ & Lobos et al., 2015 \\
\hline
\end{tabular}




\begin{tabular}{|c|c|c|c|c|c|c|}
\hline & & & & & $\begin{array}{l}\text { damage, no effect on fruit } \\
\text { nutritional quality }\end{array}$ & \\
\hline 2015 & Reflective & Kaolin & $\begin{array}{l}\text { Irrigation } \\
\text { management }\end{array}$ & Bananas & $\begin{array}{l}\text { Decreased transpiration rate and } \\
\text { amount of irrigation water, } \\
\text { increased yield }\end{array}$ & Gawad, 2015 \\
\hline 2015 & Reflective & Kaolin & Drought stress & Gooseberry & $\begin{array}{l}\text { Reduced transpiration, leaf } \\
\text { temperature, improved } \\
\text { stem elongation, total biomass and } \\
\text { WUE }\end{array}$ & $\begin{array}{l}\text { Segura-Monroy et } \\
\text { al., } 2015\end{array}$ \\
\hline 2015 & Reflective & Kaolin & $\begin{array}{l}\text { Irrigation water } \\
\text { management }\end{array}$ & Oil seed rape & Reduced irrigation frequency & $\begin{array}{l}\text { Badukale et al., } \\
2015\end{array}$ \\
\hline 2015 & Reflective & Kaolin & $\begin{array}{l}\text { Drought stress, } \\
\text { transplant } \\
\text { survival }\end{array}$ & Citrus, beans & $\begin{array}{l}\text { Decreased transplant shock, } \\
\text { improved biomass }\end{array}$ & Boari et al., 2015 \\
\hline 2015 & Reflective & Kaolin & $\begin{array}{l}\text { Irrigation water } \\
\text { management }\end{array}$ & Egg plant & $\begin{array}{l}\text { Reduced irrigation water by } 33 \% \text {, } \\
\text { increased chlorophyll content, fruit } \\
\text { weight, nutritional quality, plant } \\
\text { biomass and economic yield }\end{array}$ & El-Said, 2015 \\
\hline 2015 & Reflective & Kaolin & $\begin{array}{l}\text { Drought stress } \\
\text { and fruit quality }\end{array}$ & Olives & $\begin{array}{l}\text { Enhanced chlorophyll and } \\
\text { carotenoid contents, increased } \\
\text { oleic acid in olive oil }\end{array}$ & $\begin{array}{l}\text { Khaleghi et al., } \\
2015\end{array}$ \\
\hline 2015 & Reflective & Kaolin & $\begin{array}{l}\text { Heat and drought } \\
\text { stress }\end{array}$ & Grapes & $\begin{array}{l}\text { Higher accumulation of active } \\
\text { photosystem II reaction centres, } \\
\text { lowered mesophyll limitations, } \\
\text { increased net photosynthesis, } \\
\text { reduced sunburn, improved yield }\end{array}$ & Correia et al., 2015 \\
\hline 2015 & Reflective & $\begin{array}{l}\text { Kaolin and } \\
\text { calcium } \\
\text { carbonate }\end{array}$ & $\begin{array}{l}\text { Fruit protection } \\
\text { from sunburn }\end{array}$ & Pomegranate & $\begin{array}{l}\text { Reduced sunburn, increased } \\
\text { anthocyanin and total sugar } \\
\text { content, fruit weight and yield }\end{array}$ & El-wafa, 2015 \\
\hline 2015 & Reflective & $\begin{array}{l}\text { Potassium } \\
\text { silicate }\end{array}$ & Drought stress & Tomato & $\begin{array}{l}\text { Increased relative water content, } \\
\text { leaf expansion, WUE, plant } \\
\text { biomass and yield }\end{array}$ & $\begin{array}{l}\text { El-azm and } \\
\text { Youssef, } 2015\end{array}$ \\
\hline
\end{tabular}




\begin{tabular}{|c|c|c|c|c|c|c|}
\hline 2015 & Reflective & Kaolin & $\begin{array}{l}\text { Pest (whitefly) } \\
\text { control }\end{array}$ & Beans & $\begin{array}{l}\text { Reduced the number of eggs, } \\
\text { nymphs and adult insects by } 70,75 \\
\text { and } 80 \% \text {, respectively. Suppressed } \\
\text { transpiration by } 40 \% \text {, increased } \\
\text { chlorophyll content by } 43 \%\end{array}$ & $\begin{array}{l}\text { Nunez-Lopez et al., } \\
2015\end{array}$ \\
\hline 2015 & Reflective & Kaolin & Drought stress & $\begin{array}{l}\text { Peruvian } \\
\text { Ground Cherry }\end{array}$ & $\begin{array}{l}\text { Reduced transpiration, leaf } \\
\text { temperature, leaf thickness and } \\
\text { trichome density, increased WUE, } \\
\text { stem elongation and biomass yield }\end{array}$ & $\begin{array}{l}\text { Segura-Monroy et } \\
\text { al., } 2015\end{array}$ \\
\hline 2016 & Reflective & Kaolin & $\begin{array}{l}\text { Drought stress } \\
\text { and fruit quality }\end{array}$ & Grapes & $\begin{array}{l}\text { Improved intrinsic WUE and } \\
\text { anthocyanin content }\end{array}$ & $\begin{array}{l}\text { Brillante et al., } \\
2016\end{array}$ \\
\hline 2016 & Reflective & Kaolin & Salinity tolerance & Tomato & $\begin{array}{l}\text { Mitigated salinity stress and } \\
\text { reduced damage by insects: } \\
\text { increased marketable yield and } \\
\text { reduced sunburn by } 17.7 \text { and } \\
76.4 \% \text {, respectively, }\end{array}$ & Boari et al., 2016 \\
\hline 2016 & Reflective & Kaolin & Drought stress & Tomato & $\begin{array}{l}\text { Improved WUE, increased } \\
\text { individual fruit weight and total yield } \\
\text { by } 27 \%\end{array}$ & $\begin{array}{l}\text { Djurovic et al., } \\
2016\end{array}$ \\
\hline 2016 & Reflective & Kaolin & $\begin{array}{l}\text { Drought stress } \\
\text { and fruit quality }\end{array}$ & Grapes & $\begin{array}{l}\text { Enhanced flavonoid and } \\
\text { anthocyanin contents }\end{array}$ & Conde et al., 2016 \\
\hline 2016 & Reflective & Kaolin & Drought stress & $\begin{array}{l}\text { Tomato and } \\
\text { pepper }\end{array}$ & $\begin{array}{l}\text { Did not affect stomatal } \\
\text { conductance and plant water status } \\
\text { significantly }\end{array}$ & Cosic et al., 2016 \\
\hline 2016 & Reflective & Kaolin & $\begin{array}{l}\text { Drought and heat } \\
\text { stress; and fruit } \\
\text { quality }\end{array}$ & Grapes & $\begin{array}{l}\text { Increased phenol, flavonoid } \\
\text { anthocyanin and vitamin C } \\
\text { contents by } 40,24, \\
32 \text { and } 12 \% \text {, respectively, reduced } \\
\text { reactive oxygen species and } \\
\text { improving fruit quality }\end{array}$ & Dinis et al., 2016 \\
\hline 2016 & Reflective & Kaolin & $\begin{array}{l}\text { Heat stress } \\
\text { mitigation }\end{array}$ & Apples & $\begin{array}{l}\text { Reduced photosynthetically active } \\
\text { radiation interception, increased } \\
\text { fruit weight }\end{array}$ & Glenn, 2016 \\
\hline
\end{tabular}




\begin{tabular}{|c|c|c|c|c|c|c|}
\hline 2016 & Reflective & Kaolin & WUE & Apples & $\begin{array}{l}\text { Reduced WUE, increased stomatal } \\
\text { conductance and transpiration, } \\
\text { improved yield }\end{array}$ & Glenn, 2016b \\
\hline 2017 & Reflective & Kaolin & $\begin{array}{l}\text { Fruit protection } \\
\text { from sunburn }\end{array}$ & Grapes & Reduced sunburn & Ferrari et al., 2017 \\
\hline 2017 & Reflective & Kaolin & $\begin{array}{l}\text { Control of } \\
\text { leafhopper }\end{array}$ & Grapes & $\begin{array}{l}\text { Effective in inducing mortality of } \\
\text { nymphs }\end{array}$ & Tacoli et al., 2017 \\
\hline 2017 & Reflective & Kaolin & $\begin{array}{l}\text { Control of } \\
\text { leafhopper }\end{array}$ & Grapes & $\begin{array}{l}\text { Caused mortality of nymphs } \\
\text { through inhibition of feeding; and } \\
\text { reduced leaf symptoms and } \\
\text { damage }\end{array}$ & Tacoli et al., 2017b \\
\hline 2017 & Reflective & $\begin{array}{l}\text { Magnesium } \\
\text { carbonate, } \\
\text { sodium } \\
\text { carbonate, } \\
\text { potassium nitrate }\end{array}$ & Drought stress & Soyabeans & $\begin{array}{l}\text { Magnesium carbonate and } \\
\text { potassium nitrate improved grain } \\
\text { yield and protein content }\end{array}$ & $\begin{array}{l}\text { Dass and } \\
\text { Bhattacharyya, } \\
2017\end{array}$ \\
\hline 2017 & Reflective & $\begin{array}{l}\text { Kaolin, calcium } \\
\text { carbonate (with } \\
\text { conservation } \\
\text { tillage) }\end{array}$ & $\begin{array}{l}\text { Insect (thrips) } \\
\text { control }\end{array}$ & $\begin{array}{l}\text { Cotton and } \\
\text { groundnuts }\end{array}$ & $\begin{array}{l}\text { Increased incidence of thrips } \\
\text { (Frankliniella fusca) in cotton, } \\
\text { decreased incidence of tomato } \\
\text { spotted wilt virus in groundnuts. No } \\
\text { effect on yield in both crops }\end{array}$ & Knight et al., 2017 \\
\hline 2017 & Reflective & $\begin{array}{l}\text { Potassium } \\
\text { nitrate, } \\
\text { sodium } \\
\text { carbonate and } \\
\text { magnesium } \\
\text { carbonate }\end{array}$ & Drought stress & Soyabeans & $\begin{array}{l}\text { Increased relative water content, } \\
\text { and total biomass and grain yield }\end{array}$ & $\begin{array}{l}\text { Sanbagavalli et al., } \\
2017\end{array}$ \\
\hline 2017 & Reflective & $\begin{array}{l}\text { Kaolin, calcium } \\
\text { carbonate }\end{array}$ & $\begin{array}{l}\text { Fruit protection } \\
\text { from sunburn }\end{array}$ & Pomegranate & $\begin{array}{l}\text { Reduced sunburn damage, } \\
\text { enhanced total soluble solids }\end{array}$ & $\begin{array}{l}\text { Abdel-Sattar et al., } \\
2017\end{array}$ \\
\hline 2017 & Reflective & Kaolin & $\begin{array}{l}\text { Irrigation } \\
\text { management }\end{array}$ & Aubergine & $\begin{array}{l}\text { Reduced irrigation frequency and } \\
\text { water use, increased yield }\end{array}$ & $\begin{array}{l}\text { Abd El-Hady and } \\
\text { Doklega, } 2017\end{array}$ \\
\hline 2017 & Reflective & Kaolin & $\begin{array}{l}\text { Light extinction } \\
\text { coefficient and } \\
\text { radiation use }\end{array}$ & Pistachio & $\begin{array}{l}\text { Reduced single leaf light } \\
\text { interception but increased canopy } \\
\text { absorbance, light extinction }\end{array}$ & $\begin{array}{l}\text { Vatandoost et al., } \\
2017\end{array}$ \\
\hline
\end{tabular}




\begin{tabular}{|c|c|c|c|c|c|c|}
\hline & & & efficiency & & $\begin{array}{l}\text { coefficient }(K) \text { not significantly } \\
\text { affected, improved light use } \\
\text { efficiency in some cultivars }\end{array}$ & \\
\hline 2018 & Reflective & Kaolin & Drought stress & Olives & $\begin{array}{l}\text { Maintained leaf water status, } \\
\text { improved photosynthesis, } \\
\text { ameliorated oxidative damage, } \\
\text { whole-plant WUE and biomass not } \\
\text { improved }\end{array}$ & Brito et al., 2018 \\
\hline 2018 & Reflective & Kaolin & $\begin{array}{l}\text { Irrigation and } \\
\text { heat stress } \\
\text { management }\end{array}$ & Pepper & $\begin{array}{l}\text { Water deficit with kaolin reduced } \\
\text { canopy temperature, full irrigation } \\
\text { with kaolin increased temperature }\end{array}$ & Cosic et al., 2018 \\
\hline 2018 & Reflective & Kaolin & Heat stress & Walnut & $\begin{array}{l}\text { Decreased heat stress, enhanced } \\
\text { photosynthesis, gas exchange and } \\
\text { WUE }\end{array}$ & $\begin{array}{l}\text { Gharaghani et al., } \\
2018\end{array}$ \\
\hline 2018 & Reflective & Kaolin & $\begin{array}{l}\text { Pest (Diaphorina } \\
\text { citri) control }\end{array}$ & Citrus & $\begin{array}{l}\text { Reduction in host apparency (40\%) } \\
\text { and recognition (50\%) }\end{array}$ & $\begin{array}{l}\text { Miranda et al., } \\
2018\end{array}$ \\
\hline 2018 & Reflective & Kaolin & $\begin{array}{l}\text { Heat stress and } \\
\text { fruit quality }\end{array}$ & Grapes & $\begin{array}{l}\text { Enhanced contents of phenolic } \\
\text { compounds and anthocyanins }\end{array}$ & Kok and Bal, 2018 \\
\hline 2018 & Reflective & $\begin{array}{l}\text { Kaolin, calcium } \\
\text { carbonate }\end{array}$ & $\begin{array}{l}\text { Pest (Diaphorina } \\
\text { citri) control }\end{array}$ & Citrus & $\begin{array}{l}\text { Decreased photosynthesis (25\%), } \\
\text { leaf temperature, incidence of } \\
\text { imagoes, nymphs and egg laying }\end{array}$ & $\begin{array}{l}\text { Ramírez-Godoy et } \\
\text { al., } 2018\end{array}$ \\
\hline 2018 & Reflective & Kaolin & $\begin{array}{l}\text { Fruit protection } \\
\text { from sunburn and } \\
\text { cracking }\end{array}$ & Pomegranates & $\begin{array}{l}\text { Decreased sunburn ( } 47 \%) \text { and fruit } \\
\text { cracking }(46 \%) \text {, increased } \\
\text { anthocyanins and phenolic } \\
\text { contents and antioxidant activity }\end{array}$ & $\begin{array}{l}\text { Sharma et al., } \\
2018\end{array}$ \\
\hline 2018 & Reflective & Kaolin & Drought stress & Sunflower & $\begin{array}{l}\text { Increased chlorophyll and proline } \\
\text { contents, reduced stomatal } \\
\text { conductance and transpiration, } \\
\text { improved relative water content } \\
\text { and yield }\end{array}$ & $\begin{array}{l}\text { El Mantawy and El } \\
\text { Bialy, } 2018\end{array}$ \\
\hline 2018 & Reflective & Kaolin & Drought stress & Grapes & $\begin{array}{l}\text { Enhanced stomatal conductance, } \\
\text { photosynthesis and intrinsic WUE, } \\
\text { reduced ABA concentration, }\end{array}$ & Dinis et al., 2018 \\
\hline
\end{tabular}




\begin{tabular}{|c|c|c|c|c|c|c|}
\hline & & & & & enhanced drought tolerance. & \\
\hline 2018 & Reflective & Kaolin & Drought stress & Tomato & $\begin{array}{l}\text { Reduced canopy temperature, } \\
\text { irrigation water required, net } \mathrm{CO}_{2} \\
\text { assimilation rate and marketable } \\
\text { yield }\end{array}$ & $\begin{array}{l}\text { AbdAllah et al., } \\
2018\end{array}$ \\
\hline 2018 & Reflective & $\begin{array}{l}\text { Calcium } \\
\text { carbonate }\end{array}$ & Drought stress & Tomato & $\begin{array}{l}\text { Reduced transpiration (by } 47 \text { - } \\
58 \% \text { ) and leaf temperature, } \\
\text { improved vitamin C and total } \\
\text { phenols contents by } 15 \text { and } 12 \% \\
\text { respectively, increased antioxidant } \\
\text { activity and marketable yield }\end{array}$ & Patane et al., 2018 \\
\hline 2018 & Reflective & Kaolin & $\begin{array}{l}\text { Irrigation } \\
\text { management }\end{array}$ & Maize & $\begin{array}{l}\text { Increased leaf number and plant } \\
\text { height, improved biomass } \\
\text { accumulation }\end{array}$ & $\begin{array}{l}\text { Ulameer and } \\
\text { Ahmed, } 2018\end{array}$ \\
\hline 2018 & Reflective & Kaolin & Graft survival & Mango & $\begin{array}{l}\text { Depressed transpiration, enhanced } \\
\text { photosynthesis, increased relative } \\
\text { water content and survival of grafts }\end{array}$ & Thorat et al., 2018 \\
\hline 2018 & Reflective & Kaolin & Drought stress & Pears & $\begin{array}{l}\text { Reduced irrigation water applied, } \\
\text { elevated indoleacetic acid and } \\
\text { gibberellic acid activities }\end{array}$ & Fayed et al., 2018 \\
\hline 2018 & Reflective & $\begin{array}{l}\text { Kaolin (deficit } \\
\text { irrigation; mulch) }\end{array}$ & $\begin{array}{l}\text { Irrigation } \\
\text { management }\end{array}$ & $\begin{array}{l}\text { Common } \\
\text { Zinnia }\end{array}$ & $\begin{array}{l}\text { Increased plant height and } \\
\text { biomass accumulation }\end{array}$ & $\begin{array}{l}\text { El-Deen et al., } \\
2018\end{array}$ \\
\hline 2009 & Metabolic & ABA & $\begin{array}{l}\text { Fruit quality } \\
\text { enhancement }\end{array}$ & Grapes & $\begin{array}{l}\text { Increased anthocyanin content, } \\
\text { reduced fruit firmness, no effect on } \\
\text { soluble solids content, titratable } \\
\text { acidity, and berry size }\end{array}$ & Lurie et al., 2009 \\
\hline 2009 & Metabolic & Chitosan & Drought stress & Beans & $\begin{array}{l}\text { Depressed stomatal conductance - } \\
\text { reduced transpiration and } \\
\text { photosynthesis, mode of action } \\
\text { mediated by ABA, elevated } \\
\text { endogenous ABA concentration } \\
\text { threefold, no effect on intrinsic } \\
\text { WUE }\end{array}$ & Iriti et al., 2009 \\
\hline
\end{tabular}




\begin{tabular}{|c|c|c|c|c|c|c|}
\hline 2009 & Metabolic & $\mathrm{ABA}$ & Fruit ripening & Grapes & $\begin{array}{l}\text { Promoted fruit ripening and } \\
\text { increased berry size }\end{array}$ & $\begin{array}{l}\text { Wheeler et al., } \\
2009\end{array}$ \\
\hline 2009 & Metabolic & $\mathrm{ABA}$ & $\begin{array}{l}\text { Vase life } \\
\text { extension }\end{array}$ & $\begin{array}{l}\text { Eustoma } \\
\text { flowers }\end{array}$ & $\begin{array}{l}\text { Reduced leaf damage attributed to } \\
\text { sucrose solution, slowed loss of } \\
\text { fresh weight, extended vase life }\end{array}$ & $\begin{array}{l}\text { Shimizu-Yumoto } \\
\text { and Ichimura, } 2009\end{array}$ \\
\hline 2010 & Metabolic & ABA & Drought stress & $\begin{array}{l}\text { Various woody } \\
\text { ornamentals }\end{array}$ & $\begin{array}{l}\text { Reduced stomatal conductance } \\
\text { and cumulative water loss, } \\
\text { increased stem water potential, } \\
\text { extended marketability by one to } \\
\text { seven days }\end{array}$ & Hebert et al., 2010 \\
\hline 2010 & Metabolic & Chitosan & Drought stress & Bean & $\begin{array}{l}\text { Reduced stomatal conductance } \\
\text { and transpiration }\end{array}$ & Ludwig et al., 2010 \\
\hline 2010 & Metabolic & $\mathrm{ABA}$ & $\begin{array}{l}\text { Vase life } \\
\text { extension }\end{array}$ & Cut roses & $\begin{array}{l}\text { Pre-treatment with ABA did not } \\
\text { increase vase life but reduced } \\
\text { electrolyte leakage }\end{array}$ & $\begin{array}{l}\text { Pompodakis et al., } \\
2010\end{array}$ \\
\hline 2010 & Metabolic & $\mathrm{ABA}$ & Drought stress & $\begin{array}{l}\text { Pansy and } \\
\text { Viola }\end{array}$ & $\begin{array}{l}\text { Induced leaf chlorosis, improved } \\
\text { drought tolerance by delaying } \\
\text { wilting and maintained marketable } \\
\text { quality in the presence of } \\
\text { benzyladenine and gibberellic acid }\end{array}$ & $\begin{array}{l}\text { Waterland et al., } \\
2010\end{array}$ \\
\hline 2010 & Metabolic & $\mathrm{ABA}$ & Drought stress & $\begin{array}{l}\text { Seed } \\
\text { Geranium, } \\
\text { petunia, } \\
\text { marigold and } \\
\text { others }\end{array}$ & $\begin{array}{l}\text { Reduced water loss, induced } \\
\text { chlorosis, delayed wilting by } 1.7 \text { to } \\
4.3 \text { days }\end{array}$ & $\begin{array}{l}\text { Waterland et al., } \\
2010 a\end{array}$ \\
\hline 2010 & Metabolic & $\mathrm{ABA}$ & Drought stress & $\begin{array}{l}\text { Chrysanthemu } \\
\text { ms }\end{array}$ & $\begin{array}{l}\text { Suppressed stomatal conductance, } \\
\text { delayed wilting by } 1.2 \text { to } 4.0 \text { days, } \\
\text { induced recovery from severe } \\
\text { drought }\end{array}$ & $\begin{array}{l}\text { Waterland et al., } \\
\text { 2010c }\end{array}$ \\
\hline 2011 & Metabolic & Salicylic acid & $\begin{array}{l}\text { Vase life } \\
\text { extension }\end{array}$ & Cut roses & $\begin{array}{l}\text { Enhanced uptake of vase solution } \\
\text { increasing relative fresh weight of } \\
\text { flowers, improved antioxidant } \\
\text { activities of catalase, extending the } \\
\text { vase life }\end{array}$ & Alaey et al., 2011 \\
\hline
\end{tabular}




\begin{tabular}{|c|c|c|c|c|c|c|}
\hline 2011 & Metabolic & ABA & $\begin{array}{l}\text { Extension of shelf } \\
\text { life }\end{array}$ & Tomato & $\begin{array}{l}\text { Decreased transpiration, stomatal } \\
\text { conductance, photosynthesis and } \\
\text { irrigation water use. Increased } \\
\text { shelf life }\end{array}$ & $\begin{array}{l}\text { Astacio and van } \\
\text { lersel, } 2011\end{array}$ \\
\hline 2011 & Metabolic & ABA & Drought stress & Apples & $\begin{array}{l}\text { Enhanced water potential by } 62 \% \\
\text { and reduced endogenous leaf ABA } \\
\text { by } 45 \% \text {. }\end{array}$ & $\begin{array}{l}\text { Tworkoski et al., } \\
2011\end{array}$ \\
\hline 2011 & Metabolic & ABA & Cold tolerance & Citrus & $\begin{array}{l}\text { Reduced electrolyte } \\
\text { leakage }\end{array}$ & Yang et al., 2011 \\
\hline 2011 & Metabolic & Fulvic acid & Drought stress & Maize & $\begin{array}{l}\text { Maintained chlorophyll content } \\
\text { and gas exchange, enhanced plant } \\
\text { growth and yield }\end{array}$ & Anjum et al., 2011 \\
\hline 2011 & Metabolic & Chitosan & Disease control & Grapes & $\begin{array}{l}\text { Reduced powdery mildew } \\
\text { infestation, upregulated polyphenol } \\
\text { content and removal of free } \\
\text { radicals }\end{array}$ & Iriti et al., 2011 \\
\hline 2011 & Metabolic & ABA & $\begin{array}{l}\text { Fruit quality } \\
\text { enhancement }\end{array}$ & Grapes & $\begin{array}{l}\text { Increased anthocyanin content up } \\
\text { to } 85 \% \text {, marginal improvement of } \\
\text { total soluble solids contents }\end{array}$ & Gu et al., 2011 \\
\hline 2011 & Metabolic & ABA & Drought stress & Smoke bush & $\begin{array}{l}\text { Elevated endogenous ABA, did not } \\
\text { increased relative water content, } \\
\text { reduced stomatal conductance, } \\
\text { transpiration and photosynthesis, } \\
\text { improved drought tolerance }\end{array}$ & Li et al., 2011 \\
\hline 2011 & Metabolic & Salicylic acid & Salt stress & Sunflower & $\begin{array}{l}\text { Promoted plant growth, chlorophyll } \\
\text { and calcium contents and improved } \\
\text { leaf turgor }\end{array}$ & Noreen et al., 2011 \\
\hline 2011 & Metabolic & ABA & $\begin{array}{l}\text { Fruit quality } \\
\text { enhancement }\end{array}$ & Grapes & $\begin{array}{l}\text { Upregulated antioxidant activities } \\
\text { by } 38 \% \text {, increased anthocyanins } \\
\text { and phenolic contents }\end{array}$ & Sandhu et al., 2011 \\
\hline 2011 & Metabolic & ABA & Cold tolerance & Grapes & $\begin{array}{l}\text { Effective in inducing leaf } \\
\text { senescence, abscission and shoot } \\
\text { dormancy and promoting freeze } \\
\text { tolerance }\end{array}$ & Zhang et al., 2011 \\
\hline
\end{tabular}




\begin{tabular}{|c|c|c|c|c|c|c|}
\hline 2011 & Metabolic & $\mathrm{ABA}$ & $\begin{array}{l}\text { Vase life } \\
\text { extension }\end{array}$ & Iris flowers & $\begin{array}{l}\text { Prevented flag petal expansion, } \\
\text { induced ethylene-independent } \\
\text { senescence, upregulating } \\
\text { proteolytic degradation and } \\
\text { electrolyte leakage }\end{array}$ & $\begin{array}{l}\text { Zhong and Ciafre, } \\
2011\end{array}$ \\
\hline 2012 & Metabolic & $\mathrm{ABA}$ & Cold tolerance & Grapes & $\begin{array}{l}\text { Enhanced shoot dormancy and } \\
\text { freeze tolerance }\end{array}$ & $\begin{array}{l}\text { Zhang and Dami, } \\
2012\end{array}$ \\
\hline 2013 & Metabolic & $\mathrm{ABA}$ & Fruit ripening & Cucumber & Effective in promoting fruit ripening & Wang et al., 2013 \\
\hline 2013 & Metabolic & $\mathrm{ABA}$ & $\begin{array}{l}\text { Flowering } \\
\text { regulation }\end{array}$ & Litchi & Increased flowering per panicle & Cui et al., 2013 \\
\hline 2013 & Metabolic & Fulvic acid & Drought stress & Wheat & $\begin{array}{l}\text { Improved photosynthetic pigments, } \\
\text { increased yield }\end{array}$ & Desoky et al., 2013 \\
\hline 2013 & Metabolic & Chitosan & Drought stress & Soyabeans & $\begin{array}{l}\text { Increased yield components, } \\
\text { biomass and grain yield }\end{array}$ & Javan et al., 2013 \\
\hline 2013 & Metabolic & $\begin{array}{l}\text { Salicylic acid and } \\
\text { acetylsalicylic } \\
\text { acid }\end{array}$ & Drought stress & Fibrous flax. & $\begin{array}{l}\text { Enhanced stem elongation and } \\
\text { fibre yield }\end{array}$ & Heller et al., 2013 \\
\hline 2014 & Metabolic & $\mathrm{ABA}$ & $\begin{array}{l}\text { Fruit quality } \\
\text { enhancement }\end{array}$ & Tomato & $\begin{array}{l}\text { Increased both chlorophyll and } \\
\text { carotenoid contents in leaf and fruit } \\
\text { tissue }\end{array}$ & $\begin{array}{l}\text { Barickman et al., } \\
2014\end{array}$ \\
\hline 2014 & Metabolic & $\mathrm{ABA}$ & $\begin{array}{l}\text { Control of } \\
\text { blossom end-rot }\end{array}$ & Tomato & $\begin{array}{l}\text { Improved uptake of calcium and } \\
\text { reduced blossom end-rot }\end{array}$ & $\begin{array}{l}\text { Casey Barickman } \\
\text { et al., } 2014\end{array}$ \\
\hline 2014 & Metabolic & $\mathrm{ABA}$ & $\begin{array}{l}\text { Vase life } \\
\text { extension }\end{array}$ & Gladiolus & $\begin{array}{l}\text { Reduced water uptake, fresh } \\
\text { weight, enhanced senescence in } \\
\text { cut flowers, decreased vase life by } \\
\text { two days }\end{array}$ & Kumar et al., 2014 \\
\hline 2014 & Metabolic & $\begin{array}{l}\text { ABA (used with } \\
\qquad \text { ABA } \\
\text { Analog: (+)-8'- } \\
\text { acetylene ABA) }\end{array}$ & $\begin{array}{l}\text { Fruit set control } \\
\text { and gas } \\
\text { exchange }\end{array}$ & Apples & $\begin{array}{l}\text { Reduced stomatal conductance } \\
\text { and photosynthesis inducing a } \\
\text { decline in fruit set }\end{array}$ & $\begin{array}{l}\text { McArtney et al., } \\
2014\end{array}$ \\
\hline 2014 & Metabolic & Chitosan & Drought stress & Pomegranate & $\begin{array}{l}\text { Decreased sugar and anthocyanin } \\
\text { contents, increased fruit set, weight } \\
\text { and yield }\end{array}$ & $\begin{array}{l}\text { El-Khawaga and } \\
\text { Mansour, } 2014\end{array}$ \\
\hline
\end{tabular}




\begin{tabular}{|c|c|c|c|c|c|c|}
\hline 2014 & Metabolic & ABA & $\begin{array}{l}\text { Fruit quality } \\
\text { enhancement }\end{array}$ & Citrus & $\begin{array}{l}\text { Increased fruit size and weight, } \\
\text { enhanced potassium content, } \\
\text { reduced sugar accumulation }\end{array}$ & Kawai et al., 2014 \\
\hline 2014 & Metabolic & ABA & $\begin{array}{l}\text { Fruit quality } \\
\text { enhancement }\end{array}$ & Grapes & $\begin{array}{l}\text { No effect on cluster size or weight, } \\
\text { increased anthocyanin } \\
\text { polyphenolic compounds }\end{array}$ & $\begin{array}{l}\text { Koyama et al., } \\
2014\end{array}$ \\
\hline 2014 & Metabolic & ABA & $\begin{array}{l}\text { Protection from } \\
\text { sunburn }\end{array}$ & Apples & $\begin{array}{l}\text { No effect on sunburn, significantly } \\
\text { reduced fruit size and weight and } \\
\text { total soluble solids }\end{array}$ & $\begin{array}{l}\text { Mupambi et al., } \\
2014\end{array}$ \\
\hline 2014 & Metabolic & ABA & Transplant shock & $\begin{array}{l}\text { Leafy } \\
\text { vegetables }\end{array}$ & $\begin{array}{l}\text { Improved quality of seedlings pre- } \\
\text { planting, increased marketability of } \\
\text { spinach at harvest }\end{array}$ & Racsko et al., 2014 \\
\hline 2014 & Metabolic & ABA & Transplant shock & Artichoke & $\begin{array}{l}\text { Induced stomatal closure, } \\
\text { increased plant water potential, } \\
\text { reduced electrolyte leakage, } \\
\text { enhanced drought tolerance }\end{array}$ & $\begin{array}{l}\text { Shinohara and } \\
\text { Leskovar, } 2014\end{array}$ \\
\hline 2014 & Metabolic & $\mathrm{ABA}$ & Drought stress & Pansies & $\begin{array}{l}\text { Decreased leaf chlorophyll content, } \\
\text { stomatal conductance and carbon } \\
\text { assimilation, induced chlorosis. }\end{array}$ & $\begin{array}{l}\text { Weaver and van } \\
\text { lersel, } 2014\end{array}$ \\
\hline 2015 & Metabolic & $\mathrm{ABA}$ & $\begin{array}{l}\text { Vase life } \\
\text { extension }\end{array}$ & $\begin{array}{l}\text { Lilium } \\
\text { Sorbonne }\end{array}$ & $\begin{array}{l}\text { Increased sucrose uptake from } \\
\text { solution, contents of simple sugars } \\
\text { and fresh weight }\end{array}$ & Geng et al., 2015 \\
\hline 2015 & Metabolic & $\mathrm{ABA}$ & Cold tolerance & Grapes & $\begin{array}{l}\text { Enhanced cold tolerance, did not } \\
\text { have an effect on yield and berry } \\
\text { quality, no evidence of toxicity }\end{array}$ & Dami et al., 2015 \\
\hline 2015 & Metabolic & $\mathrm{ABA}$ & $\begin{array}{l}\text { Fruit quality } \\
\text { enhancement }\end{array}$ & Grapes & $\begin{array}{l}\text { Increased anthocyanin content, } \\
\text { antioxidant activity and bunch yield }\end{array}$ & Ferrara et al., 2015 \\
\hline 2015 & Metabolic & $\mathrm{ABA}$ & $\begin{array}{l}\text { Fruit quality } \\
\text { enhancement }\end{array}$ & Grapes & $\begin{array}{l}\text { Increased anthocyanins content } \\
\text { and improved flavour of juice }\end{array}$ & $\begin{array}{l}\text { Yamamoto et al., } \\
2015\end{array}$ \\
\hline 2015 & Metabolic & Fulvic acid & Drought stress & Tomato & $\begin{array}{l}\text { Improved relative water content } \\
\text { and marketable yield by } 24 \% \text {, } \\
\text { irrigation WUE by } 34.82 \% \text {. }\end{array}$ & Aggag et al., 2015 \\
\hline
\end{tabular}




\begin{tabular}{|c|c|c|c|c|c|c|}
\hline 2015 & Metabolic & Fulvic acid & Drought stress & Oil seed rape & $\begin{array}{l}\text { Enhanced maximum quantum } \\
\text { efficiency of photosystem II, } \\
\text { fluorescence of chlorophyll a, } \\
\text { antioxidant activities, ameliorated } \\
\text { lipid peroxidation. }\end{array}$ & Lotfi et al., 2015 \\
\hline 2016 & Metabolic & ABA & Drought stress & Apple & $\begin{array}{l}\text { Depressed gas exchange } \\
\text { variables, water deficit stress not } \\
\text { alleviated }\end{array}$ & $\begin{array}{l}\text { Al-Absi and } \\
\text { Archbold, } 2016\end{array}$ \\
\hline 2016 & Metabolic & ABA & Cold stress & Blueberry & $\begin{array}{l}\text { Reduced electrolyte leakage of } \\
\text { floral parts increasing their } \\
\text { tolerance to freezing injury }\end{array}$ & $\begin{array}{l}\text { Panicker and } \\
\text { Matta, } 2016\end{array}$ \\
\hline 2016 & Metabolic & ABA & Cold stress & Grapes & Reduced bud damage & Bowen et al., 2016 \\
\hline 2016 & Metabolic & $\begin{array}{l}\text { Acetylsalicylic } \\
\text { acid }\end{array}$ & $\begin{array}{l}\text { Vase life } \\
\text { extension }\end{array}$ & Cut roses & $\begin{array}{l}\text { Reduced transpiration, extended } \\
\text { vase life }\end{array}$ & $\begin{array}{l}\text { Fanourakis et al., } \\
2016\end{array}$ \\
\hline 2016 & Metabolic & ABA & $\begin{array}{l}\text { Cold stress and } \\
\text { fruit quality }\end{array}$ & Grapes & $\begin{array}{l}\text { Induced early leaf senescence, } \\
\text { abscission, enhanced dormancy, } \\
\text { increased cold tolerance }\end{array}$ & Li and Dami, 2016 \\
\hline 2016 & Metabolic & ABA & $\begin{array}{l}\text { Fruit quality } \\
\text { enhancement }\end{array}$ & Grapes & $\begin{array}{l}\text { Upregulated flavonoid and } \\
\text { anthocyanin biosynthesis genes, } \\
\text { increased anthocyanin content }\end{array}$ & $\begin{array}{l}\text { Katayama-lkegami } \\
\text { et al., } 2016\end{array}$ \\
\hline 2016 & Metabolic & ABA & Drought stress & $\begin{array}{l}\text { Various } \\
\text { bedding plants }\end{array}$ & $\begin{array}{l}\text { Depressed stomatal conductance, } \\
\text { improved drought tolerance by } \\
\text { delaying wilting by between } 1.3 \\
\text { and } 3.7 \text { days }\end{array}$ & Park et al., 2016 \\
\hline 2016 & Metabolic & ABA & $\begin{array}{l}\text { Fruit quality } \\
\text { enhancement }\end{array}$ & Grapes & $\begin{array}{l}\text { Improved berry and bunch sizes, } \\
\text { total soluble solids and fruit } \\
\text { firmness }\end{array}$ & Singh et al., 2016 \\
\hline 2016 & Metabolic & Fulvic acid & $\begin{array}{l}\text { Water deficit } \\
\text { conditions }\end{array}$ & Wheat & $\begin{array}{l}\text { Improved WUE, carbon } \\
\text { assimilation and yield }\end{array}$ & Zhang et al., 2016 \\
\hline 2016 & Metabolic & $\mathrm{ABA}$ & $\begin{array}{l}\text { Water deficit } \\
\text { conditions }\end{array}$ & Grapes & $\begin{array}{l}\text { Reduced electrolyte leakage and } \\
\text { lipid peroxidation, improved } \\
\text { antioxidant activity }\end{array}$ & Wang et al., 2016 \\
\hline 2016 & Metabolic & ABA & Water deficit & Wheat & Improved WUE and yield & Zhang et al., 2016 \\
\hline
\end{tabular}




\begin{tabular}{|c|c|c|c|c|c|c|}
\hline 2017 & Metabolic & ABA & Fruit thinning & Pears & $\begin{array}{l}\text { Suppression of net photosynthesis } \\
\text { by } 75-90 \% \text {, increased fruit size, } \\
\text { fruit quality unaffected }\end{array}$ & $\begin{array}{l}\text { Arrington et al., } \\
2017\end{array}$ \\
\hline 2017 & Metabolic & $\begin{array}{l}\text { Salicylic acid, } \\
\text { Benzoic acid }\end{array}$ & Drought stress & Tomato & $\begin{array}{l}\text { Increased leaf area index, fruit } \\
\text { number and marketable yield }\end{array}$ & Isa et al., 2017 \\
\hline 2017 & Metabolic & $\mathrm{ABA}$ & $\begin{array}{l}\text { Fruit quality } \\
\text { enhancement }\end{array}$ & Tomato & $\begin{array}{l}\text { Enhanced the concentrations of } \\
\text { fructose, glucose and the contents } \\
\text { of chlorophyll and carotenoids }\end{array}$ & $\begin{array}{l}\text { Barickman et al., } \\
2017\end{array}$ \\
\hline 2017 & Metabolic & ABA & $\begin{array}{l}\text { Fruit quality } \\
\text { enhancement }\end{array}$ & Grapes & $\begin{array}{l}\text { Elevated accumulation of ethanol, } \\
\text { depressed aroma quality }\end{array}$ & $\begin{array}{l}\text { Gonzalez et al., } \\
2018\end{array}$ \\
\hline 2017 & Metabolic & Salicylic acid & $\begin{array}{l}\text { Vase life } \\
\text { extension }\end{array}$ & Cut roses & $\begin{array}{l}\text { Sustained membrane stability, } \\
\text { attenuated lipid peroxidation, } \\
\text { reduced weight loss, enhanced } \\
\text { antioxidant activities, extended } \\
\text { vase life }\end{array}$ & Kazemi et al., 2017 \\
\hline 2017 & Metabolic & Chitosan & $\begin{array}{l}\text { Vase life } \\
\text { extension }\end{array}$ & Macaw flower & $\begin{array}{l}\text { Increased anthocyanin and } \\
\text { flavonoid contents by } 48 \text { and } 46 \% \text {, } \\
\text { respectively, sustained fresh } \\
\text { weight, extended vase life by } 10.3 \\
\text { days }\end{array}$ & $\begin{array}{l}\text { Banuelos- } \\
\text { Hernandez et al., } \\
2017\end{array}$ \\
\hline 2017 & Metabolic & ABA & $\begin{array}{l}\text { Fruit quality } \\
\text { enhancement }\end{array}$ & Grapes & $\begin{array}{l}\text { Enhanced soluble solids, } \\
\text { anthocyanin and total phenolic } \\
\text { contents }\end{array}$ & Neto et al., 2017 \\
\hline 2017 & Metabolic & ABA & $\begin{array}{l}\text { Post-harvest } \\
\text { preservation }\end{array}$ & Grapes & $\begin{array}{l}\text { Decreased shatter, decay and loss } \\
\text { of fruit weight }\end{array}$ & $\begin{array}{l}\text { F. J. D. Neto et al., } \\
2017\end{array}$ \\
\hline 2017 & Metabolic & $\mathrm{ABA}$ & $\begin{array}{l}\text { Fruit quality } \\
\text { enhancement }\end{array}$ & Grapes & $\begin{array}{l}\text { Upregulated anthocyanin } \\
\text { biosynthesis genes, elevated } \\
\text { anthocyanins content }\end{array}$ & $\begin{array}{l}\text { Olivares et al., } \\
2017\end{array}$ \\
\hline 2017 & Metabolic & ABA & $\begin{array}{l}\text { Berry and cluster } \\
\text { manipulation }\end{array}$ & Grapes & $\begin{array}{l}\text { Reduced berry number, improved } \\
\text { berry and cluster uniformity }\end{array}$ & $\begin{array}{l}\text { Padmalatha et al., } \\
2017\end{array}$ \\
\hline 2017 & Metabolic & ABA & $\begin{array}{l}\text { Extension of } \\
\text { marketability }\end{array}$ & Tomato & $\begin{array}{l}\text { Inhibited stem elongation, leaf } \\
\text { expansion and shoot biomass } \\
\text { accumulation by } 22 \% \text { effectively }\end{array}$ & $\begin{array}{l}\text { Agehara and } \\
\text { Leskovar, } 2017\end{array}$ \\
\hline
\end{tabular}




\begin{tabular}{|c|c|c|c|c|c|c|}
\hline & & & & & prolonging market value & \\
\hline 2017 & Metabolic & Chitosan & Drought stress & White clover & $\begin{array}{l}\text { Increased contents of amino acids, } \\
\text { sugars, sugar alcohols, } \\
\text { antioxidants and other metabolites } \\
\text { associated with drought resistance } \\
\text { mechanisms }\end{array}$ & Z. Li et al., 2017 \\
\hline 2017 & Metabolic & Fulvic acid & Crop productivity & Safflower & $\begin{array}{l}\text { Improved seed yield by } 36 \% \text { and } \\
\text { oil content by } 86 \%\end{array}$ & Moradi et al., 2017 \\
\hline 2018 & Metabolic & ABA & $\begin{array}{l}\text { Stomatal } \\
\text { physiology }\end{array}$ & Cut gerberas & $\begin{array}{l}\text { Increased percentage of closed } \\
\text { stomata, reduced stomatal } \\
\text { aperture, decreased water loss }\end{array}$ & Huang et al., 2018 \\
\hline 2018 & Metabolic & ABA & $\begin{array}{l}\text { Fruit quality } \\
\text { enhancement }\end{array}$ & Grapes & $\begin{array}{l}\text { Increased anthocyanin and aroma } \\
\text { volatiles contents, decreased fruit } \\
\text { firmness }\end{array}$ & Jia et al., 2018 \\
\hline 2018 & Metabolic & ABA & $\begin{array}{l}\text { Fruit quality } \\
\text { enhancement }\end{array}$ & Grapes & $\begin{array}{l}\text { Enhanced phenolic } \\
\text { compounds and anthocyanin } \\
\text { contents, increased grape yield }\end{array}$ & $\begin{array}{l}\text { Kok and Bal, } \\
2018 \mathrm{~b}\end{array}$ \\
\hline 2018 & Metabolic & ABA & $\begin{array}{l}\text { Fruit quality } \\
\text { enhancement }\end{array}$ & Grapes & $\begin{array}{l}\text { Upregulated anthocyanin and } \\
\text { flavonoid gene expression }\end{array}$ & $\begin{array}{l}\text { Koyama et al., } \\
2018\end{array}$ \\
\hline 2018 & Metabolic & ABA & $\begin{array}{l}\text { Fruit quality } \\
\text { enhancement }\end{array}$ & Blueberry & $\begin{array}{l}\text { Elevated endogenous ABA, } \\
\text { increased anthocyanins (malvidin, } \\
\text { delphinidin, petunidin glycosides) } \\
\text { and fruit softening }\end{array}$ & Oh et al., 2018 \\
\hline 2018 & Metabolic & ABA & $\begin{array}{l}\text { Fruit quality } \\
\text { enhancement }\end{array}$ & Oranges & $\begin{array}{l}\text { Enhanced colour index and } \\
\text { carotenoid content, reduced } \\
\text { organic acids, no effect on sugar } \\
\text { content }\end{array}$ & $\begin{array}{l}\text { Rehman et al., } \\
2018\end{array}$ \\
\hline 2018 & Metabolic & Chitosan & Drought stress & Wheat & $\begin{array}{l}\text { Improved chlorophyll, carotenoid, } \\
\text { proline and superoxide dismutase } \\
\text { contents }\end{array}$ & Singh et al., 2018 \\
\hline 2018 & Metabolic & $\begin{array}{l}\text { Chitosan, deficit } \\
\text { irrigation }\end{array}$ & $\begin{array}{l}\text { Irrigation } \\
\text { management }\end{array}$ & Wheat & $\begin{array}{l}\text { Increased stem extension and leaf } \\
\text { expansion }\end{array}$ & Reddy et al., 2018 \\
\hline
\end{tabular}




\begin{tabular}{|c|c|c|c|c|c|c|}
\hline 2018 & Metabolic & Fulvic acid & $\begin{array}{l}\text { Low } \\
\text { rainfall/drought } \\
\text { stress }\end{array}$ & Maize & $\begin{array}{l}\text { Increased kernel number per ear, } \\
\text { did not increase yield }\end{array}$ & Yang et al., 2018 \\
\hline 2018 & Metabolic & Fulvic acid & Drought stress & Tomato & $\begin{array}{l}\text { Reduced canopy temperature, } \\
\text { irrigation water required (by } 28 \% \text { ), } \\
\text { net } \mathrm{CO}_{2} \text { assimilation rate and } \\
\text { marketable yield, increased WUE } \\
\text { by } 33.45 \%\end{array}$ & $\begin{array}{l}\text { AbdAllah et al., } \\
2018\end{array}$ \\
\hline 2018 & Metabolic & $\begin{array}{l}\text { Phenyl mercuric } \\
\text { acetate }\end{array}$ & Drought stress & Oil seed rape & $\begin{array}{l}\text { Increased plant height and total } \\
\text { biomass, but not seed oil and } \\
\text { protein contents }\end{array}$ & Kumar et al., 2018 \\
\hline 2009 & Film-forming & Di-1-p-menthene & Drought stress & Kiwi fruit & $\begin{array}{l}\text { Enhanced efficiency of } \\
\text { photosystem II and chlorophyll } \\
\text { content, non-significant effect on } \\
\text { yield }\end{array}$ & $\begin{array}{l}\text { Latocha et al., } \\
2009\end{array}$ \\
\hline 2009 & Film-forming & Di-1-p-menthene & Drought stress & Sultani fig & $\begin{array}{l}\text { Reduced sugars and total soluble } \\
\text { solids, improved vegetative growth } \\
\text { and yield }\end{array}$ & $\begin{array}{l}\text { Al-Desouki et al., } \\
2009\end{array}$ \\
\hline 2009 & Film-forming & Di-1-p-menthene & $\begin{array}{l}\text { Physiology, } \\
\text { nutrient uptake } \\
\text { and yield }\end{array}$ & Pepper & $\begin{array}{l}\text { Suppressed carbon assimilation, } \\
\text { reduced water absorption, no effect } \\
\text { on cation uptake and dry weight } \\
\text { and yield, reduced incidence of } \\
\text { blossom-end rot }\end{array}$ & $\begin{array}{l}\text { del Amor and } \\
\text { Rubio, } 2009\end{array}$ \\
\hline 2009 & Film-forming & $\begin{array}{l}\text { Canola oil } \\
\text { (other vegetable } \\
\text { oils) }\end{array}$ & $\begin{array}{l}\text { Control of } \\
\text { powdery and } \\
\text { downy mildews }\end{array}$ & Cucumber & $\begin{array}{l}\text { Reduced powdery and downy } \\
\text { mildews by } 99 \text { and } 96 \% \text {, } \\
\text { respectively }\end{array}$ & Jee et al., 2009 \\
\hline 2009 & Film-forming & $\begin{array}{l}\text { Di-1-p-menthene, } \\
\text { poly-1-p } \\
\text { menthene }\end{array}$ & $\begin{array}{l}\text { Control of apple } \\
\text { scab (Venturia } \\
\text { inaequalis) }\end{array}$ & Apples & $\begin{array}{l}\text { Increased chlorophyll fluorescence, } \\
\text { decreased conidia germination and } \\
\text { foliar and fruit scab severity, } \\
\text { improved yield }\end{array}$ & $\begin{array}{l}\text { Percival and Boyle } \\
2009\end{array}$ \\
\hline 2010 & Film-forming & Di-1-p-menthene & Drought stress & Wheat & $\begin{array}{l}\text { Improved yield at high soil water } \\
\text { deficit }\end{array}$ & $\begin{array}{l}\text { Kettlewell et al., } \\
2010\end{array}$ \\
\hline
\end{tabular}




\begin{tabular}{|c|c|c|c|c|c|c|}
\hline 2010 & Film-forming & Di-1-p-menthene & Drought stress & Wheat & Improved yield & $\begin{array}{l}\text { Kettlewell and } \\
\text { Holloway, } 2010\end{array}$ \\
\hline 2010 & Film-forming & Di-1-p-menthene & Drought stress & Bean & Reduced stomatal conductance & Ludwig et al., 2010 \\
\hline 2010 & Film-forming & Di-1-p-menthene & Drought stress & Pepper & $\begin{array}{l}\text { Reduced gas exchange under } \\
\text { ambient } \mathrm{CO}_{2} \text { concentration, higher } \\
\text { water potential and photosynthesis } \\
\text { under combined elevated } \mathrm{CO}_{2} \text { and } \\
\text { AT }\end{array}$ & $\begin{array}{l}\text { del Amor et al., } \\
2010\end{array}$ \\
\hline 2010 & Film-forming & Di-1-p-menthene & Drought stress & Citrus & $\begin{array}{l}\text { Non-significant effect on gas } \\
\text { exchange, plant water status, } \\
\text { chlorophyll and proline contents }\end{array}$ & $\begin{array}{l}\text { Mohawesh et al., } \\
2010\end{array}$ \\
\hline 2010 & Film-forming & Di-1-p-menthene & $\begin{array}{l}\text { Fruit quality } \\
\text { control }\end{array}$ & Grapes & $\begin{array}{l}\text { Depressed transpiration and } \\
\text { carbon assimilation rates, } \\
\text { increased intrinsic WUE and } \\
\text { anthocyanin content, reduced yield }\end{array}$ & Palliotti et al., 2010 \\
\hline 2011 & Film-forming & Di-1-p-menthene & Ozone stress & Beans & $\begin{array}{l}\text { Reduced membrane damage, } \\
\text { maintained stomatal conductance } \\
\text { and photosynthesis }\end{array}$ & $\begin{array}{l}\text { Francini et al., } \\
2011\end{array}$ \\
\hline 2012 & Film-forming & $\begin{array}{l}\text { Carboxylated } \\
\text { hydrophilic } \\
\text { polymer (Envy) }\end{array}$ & Transplant shock & Agarwood & $\begin{array}{l}\text { Neither improved growth rates nor } \\
\text { reduce stress and mortality of } \\
\text { transplants }\end{array}$ & $\begin{array}{l}\text { Page and Awarau, } \\
2012\end{array}$ \\
\hline 2013 & Film-forming & Castor bean oil & Drought stress & Soyabeans & $\begin{array}{l}\text { Increased yield components, } \\
\text { biomass and grain yield }\end{array}$ & Javan et al., 2013 \\
\hline 2013 & Film-forming & Di-1-p-menthene & $\begin{array}{l}\text { Micronutrient and } \\
\text { trace element } \\
\text { quality }\end{array}$ & Sweet cherry & $\begin{array}{l}\text { No effect on quantity of } \\
\text { manganese, nickel, cadmium, } \\
\text { copper or zinc }\end{array}$ & $\begin{array}{l}\text { Mikiciuk et al., } \\
2013\end{array}$ \\
\hline 2013 & Film-forming & Di-1-p-menthene & $\begin{array}{l}\text { Control of sugar } \\
\text { content }\end{array}$ & Grapes & $\begin{array}{l}\text { Reduced transpiration, } \\
\text { photosynthesis, intrinsic WUE, } \\
\text { anthocyanin content (by 19\%) and } \\
\text { sugar content }\end{array}$ & Palliotti et al., 2013 \\
\hline 2014 & Film-forming & Di-1-p-menthene & Drought stress & $\begin{array}{l}\text { Wheat and } \\
\text { barley }\end{array}$ & $\begin{array}{l}\text { Improved water potential in both } \\
\text { crops, increased photosynthesis in } \\
\text { wheat only }\end{array}$ & $\begin{array}{l}\text { Ouerghi et al., } \\
2014\end{array}$ \\
\hline
\end{tabular}




\begin{tabular}{|c|c|c|c|c|c|c|}
\hline 2015 & Film-forming & Di-1-p-menthene & Drought stress & Wheat & $\begin{array}{l}\text { Improved plant water status, } \\
\text { photosynthesis and yield }\end{array}$ & $\begin{array}{l}\text { Abdullah et al., } \\
2015\end{array}$ \\
\hline 2015 & Film-forming & Paraffin & Drought stress & Potatoes & $\begin{array}{l}\text { Reduced transpiration, improved } \\
\text { WUE, total yield and marketable } \\
\text { yield }\end{array}$ & $\begin{array}{l}\text { Khalel, A. M. S., } \\
2015\end{array}$ \\
\hline 2015 & Film-forming & Di-1-p-menthene & & Strawberry & $\begin{array}{l}\text { Reduced transpiration without } \\
\text { depressing carbon assimilation, } \\
\text { increased relative water content } \\
\text { and WUE, no effect on chlorophyll }\end{array}$ & $\begin{array}{l}\text { Mikiciuk et al., } \\
2015\end{array}$ \\
\hline 2016 & Film-forming & Di-1-p-menthene & Drought stress & Wheat & $\begin{array}{l}\text { Improved water potential, pollen } \\
\text { viability and grain yield }\end{array}$ & $\begin{array}{l}\text { Weerasinghe et al. } \\
2016\end{array}$ \\
\hline 2016 & Film-forming & $\begin{array}{l}\text { Poly-1- } p \text { - } \\
\text { menthene and di- } \\
1-p-\text { menthene }\end{array}$ & Drought stress & Oil seed rape & $\begin{array}{l}\text { Decreased endogenous ABA, } \\
\text { improved flower and pod water } \\
\text { potential. }\end{array}$ & Faralli et al., 2016 \\
\hline 2016 & Film-forming & Di-1-p-menthene & Fruit quality & Grapes & $\begin{array}{l}\text { No effect on intrinsic WUE, } \\
\text { depressed gas exchange, sugar } \\
\text { and anthocyanin content }\end{array}$ & $\begin{array}{l}\text { Brillante et al., } \\
2016\end{array}$ \\
\hline 2016 & Film-forming & Di-1-p-menthene & $\begin{array}{l}\text { Controlled } \\
\text { ripening }\end{array}$ & Grapes & $\begin{array}{l}\text { Reduced gas exchange, slowed } \\
\text { sugar accumulation }\end{array}$ & Gatti et al., 2016 \\
\hline 2017 & Film-forming & $\begin{array}{l}\text { Poly-1- } p \text { - } \\
\text { menthene and di- } \\
1-p \text {-menthene }\end{array}$ & Drought stress & Oil seed rape & $\begin{array}{l}\text { Reduced transpiration and } \\
\text { stomatal conductance, enhanced } \\
\text { water potential and yield }\end{array}$ & Faralli et al., 2017 \\
\hline 2017 & Film-forming & Di-1-p-menthene & Drought stress & Oil seed rape & $\begin{array}{l}\text { Reduced } \mathrm{CO}_{2} \text { assimilation and } \\
\text { relative water content, increased } \\
\text { intrinsic WUE }\end{array}$ & $\begin{array}{l}\text { M. Faralli et al., } \\
2017\end{array}$ \\
\hline 2018 & Film-forming & $\begin{array}{l}\text { Poly-1-p- } \\
\text { menthene }\end{array}$ & $\begin{array}{l}\text { Vase life } \\
\text { extension }\end{array}$ & Roses & $\begin{array}{l}\text { Reduced transpiration, increased } \\
\text { vase life }\end{array}$ & $\begin{array}{l}\text { Di Stasio et al., } \\
2018\end{array}$ \\
\hline 2018 & Film-forming & Di-1-p-menthene & Drought stress & Grapes & $\begin{array}{l}\text { Reduced both leaf and bunch } \\
\text { stomatal conductance, } \\
\text { photosynthesis and transpiration, } \\
\text { elevated leaf and berry } \\
\text { temperature }\end{array}$ & $\begin{array}{l}\text { Fahey and } \\
\text { Rogiers, } 2018\end{array}$ \\
\hline
\end{tabular}


683 Conflicts of Interest

684 The authors declare no conflicts of interest.

\section{Acknowledgements}

686 This paper was written during the tenure of a Commonwealth Scholarship

687 awarded to Wiza Mphande

688

689

690

691

692

693

694

695

696

697

698

699

700

701

702

703

704

705 


\section{References}

Abd El-Hady, M., Doklega, S., 2017. Response of Two Eggplant Cultivars to Irrigation Intervals and Foliar Application with some Antitranspirants. J. Plant Prod. 8, 1395-1401. https://doi.org/10.21608/jpp.2017.42015

AbdAllah, A.M., Burkey, K.O., Mashaheet, A.M., 2018. Reduction of plant water consumption through anti-transpirants foliar application in tomato plants (Solanum lycopersicum L). Sci. Hortic. (Amsterdam). 235, 373-381. https://doi.org/10.1016/j.scienta.2018.03.005

AbdAllah, A.M., Mashaheet, A.M., Zobel, R., Burkey, K.O., 2019. Physiological basis for controlling water consumption by two snap beans genotypes using different anti-transpirants. Agric. Water Manag. 214, 17-27. https://doi.org/10.1016/j.agwat.2018.12.029

Abdel-Sattar, M., Eissa, A.M., El-shazly, S.M., Alabd, A.., 2017. Improving Quality of Wonderful Pomegranate by Using Bagging and Different Agrochemical Treatments. Alexandria J. Agric. Sci. 2017, 103-109. https://doi.org/10.21608/alexja.2017.5760

Abdullah, A.S., Aziz, M.M., Siddique, K.H.M., Flower, K.C., 2015. Film antitranspirants increase yield in drought stressed wheat plants by maintaining high grain number. Agric. Water Manag. 159, 11-18. https://doi.org/10.1016/j.agwat.2015.05.018

Abou-Khaled, A., Hagan, R.M., Davenport, D.C., 1970. Effects of kaolinite as a reflective antitranspirant on leaf temperature, transpiration, photosynthesis, and water-use efficiency. Water Resour. Res. 6, 280-289. https://doi.org/10.1081/E-EBBE

Agarwal, S.K., 1979. Effect of nitrogen rates, mulching and antitranspirants on water use and water use efficiency of barley (hordeum vulgare I.) varieties grown under dryland conditions. J. Agric. Sci. 92, 263-268. https://doi.org/10.1017/S0021859600062754

Agehara, S., Leskovar, D.I., 2017. Growth suppression by exogenous abscisic acid and uniconazole for prolonged marketability of tomato transplants in commercial conditions. HortScience 52, 606-611. https://doi.org/10.21273/HORTSCI11518-16

Aggag, A.M., Alzoheiry, A.M., Abdallah, A.E., 2015. Effect of Kaolin and Fulvic Acid Antitranspirants on Tomato Plants Grown under Different Water Regimes. Alexandria Sci. Exch. J. 36, 169-179. https://doi.org/10.21608/asejaiqjsae.2015.2875

AgroBest Australia, 2017. Envy safety data sheet [WWW Document]. URL http://www.agrobest.com.au/files/MSDS/Envy_2017.pdf (accessed 6.23.19).

Ahmed, F.F., Abdel Aal, A.M.K., El- Sayed, M.A., Sayed, H.R., 2013. Protecting Red Roomy Grapevines Growing Under Minia Region Conditions from Sunburn Damage. Stem Cell 4, 15-20.

Al-Absi, K., Archbold, D., 2016. Apple Tree Responses to Deficit Irrigation Combined with Periodic Applications of Particle Film or Abscisic Acid. 
Al-Desouki, M.I., El-Rhman, I.E.A., Sahar, A.F., 2009. Effect of Some Antitranspirants and Supplementery Irrigation on Growth, Yield and Fruit Quality of Sultani Fig (Ficus Carica) Grown in the Egyption Western Coastal Zone under Rainfed Conditions. Res. J. Agric. Biol. Sci. 5, 899-908.

Alaey, M., Babalar, M., Naderi, R., Kafi, M., 2011. Effect of pre- and postharvest salicylic acid treatment on physio-chemical attributes in relation to the vase life of cut rose flowers. Postharvest Biol. Technol. 61, 91-94. https://doi.org/https://doi.org/10.1016/j.postharvbio.2011.02.002

Alavo, T.B.C., Yarou, B.B., Atachi, P., 2010. Field effects of kaolin particle film formulation against major cotton lepidopteran pests in North Benin, West Africa. Int. J. Pest Manag. 56, 287-290. https://doi.org/10.1080/09670871003628389

Alghabari, F., Lukac, M., Jones, H.E., Gooding, M.J., 2013. Effect of Rht Alleles on the Tolerance of Wheat Grain Set to High Temperature and Drought Stress During Booting and Anthesis. J. Agron. Crop Sci. 200, 36-45. https://doi.org/10.1111/jac.12038

Aly, M., El-megeed, N.A., Awad, R.M., 2010. Reflective Particle Films Affected on , Sunburn , Yield, Mineral Composition and Fruit Maturity of 'Anna ' Apple ( Malus domestica ) Trees . 6, 84-92.

Anjum, S.A., Wang, L., Farooq, M., Xue, L., Ali, S., 2011. Fulvic Acid Application Improves the Maize Performance under Well-watered and Drought Conditions. J. Agron. Crop Sci. 197, 409-417. https://doi.org/10.1111/j.1439037X.2011.00483.x

Arrington, M., Pasa, M.S., Einhorn, T.C., 2017. Postbloom thinning response of 'Bartlett' pears to abscisic acid. HortScience 52, 1765-1771. https://doi.org/10.21273/HORTSCI12429-17

Arve, L.E., Carvalho, D.R.A., Olsen, J.E., Torre, S., 2014. ABA induces H 2 O 2 production in guard cells, but does not close the stomata on Vicia faba leaves developed at high air humidity 1-9.

Astacio, M.G., van lersel, M.W., 2011. Determining the effects of abscisic acid drenches on evapotranspiration and leaf gas exchange of tomato. HortScience 46, 1512-1517. https://doi.org/10.21273/hortsci.46.11.1512

Azizi, A., Hokmabadi, H., Piri, S., Rabie, V., 2013. Effect of Kaolin Application on Water Stress in P istachio cv . " Ohadi ". J. Nuts 4, 9-14.

Badukale, K.E., Mankar, D.D., Jaiswal, S.G., Desai, A., 2015. Effect of antitranspirants and frequency of irrigations on growth, yield attributes and yield of Indian mustard (Brassica juncea L.). J. Soils Crop. 25, 210-214.

Bai, Y., Wu, F., Xing, B., Meng, W., Shi, G., Ma, Y., Giesy, J.P., 2015. Isolation and characterization of chinese standard fulvic acid sub-fractions separated from forest soil by stepwise elution with pyrophosphate buffer. Sci. Rep. 5, 18. https://doi.org/10.1038/srep08723

Banuelos-Hernandez, K.P., Garcia-Nava, J.R., Leyva-Ovalle, O.R., Pena-Valdivia, C.B., Trejo, C., Ybarra-Moncada, M.C., 2017. Chitosan coating effect on vase 
life of flowering stems of Heliconia bihai (L.) L. cv. Halloween. Postharvest Biol. Technol. 132, 179-187. https://doi.org/10.1016/j.postharvbio.2017.05.009

Barber, H.M., Carney, J., Alghabari, F., Gooding, M.J., 2015. Decimal growth stages for precision wheat production in changing environments? Ann. Appl. Biol. 166, 355-371. https://doi.org/10.1111/aab.12207

Barickman, T.C., Kopsell, D.A., Sams, C.E., 2017. Abscisic acid improves tomato fruit quality by increasing soluble sugar concentrations. J. Plant Nutr. 40, 964973. https://doi.org/10.1080/01904167.2016.1231812

Barickman, T.C., Kopsell, D.A., Sams, C.E., 2014. Abscisic acid increases carotenoid and chlorophyll concentrations in leaves and fruit of two tomato genotypes. J. Am. Soc. Hortic. Sci. 139, 261-266. https://doi.org/10.21273/jashs.139.3.261

Bistgani, Z.E., Siadat, S.A., Bakhshandeh, A., Pirbalouti, A.G., Hashemi, M., 2017. Interactive effects of drought stress and chitosan application on physiological characteristics and essential oil yield of Thymus daenensis Celak. Crop J. 5, 407-415. https://doi.org/10.1016/j.cj.2017.04.003

Bloomfield, K.J., Prentice, I.C., Cernusak, L.A., Eamus, D., Medlyn, B.E., Rumman, R., Wright, I.J., Boer, M.M., Cale, P., Cleverly, J., Egerton, J.J.G., Ellsworth, D.S., Evans, B.J., Hayes, L.S., Hutchinson, M.F., Liddell, M.J., Macfarlane, C., Meyer, W.S., Togashi, H.F., Wardlaw, T., Zhu, L., Atkin, O.K., 2019. The validity of optimal leaf traits modelled on environmental conditions. New Phytol. 221, 1409-1423. https://doi.org/10.1111/nph.15495

Boari, F., Donadio, A., Pace, B., Schiattone, M.I., Cantore, V., 2016. Kaolin improves salinity tolerance, water use efficiency and quality of tomato. Agric. Water Manag. 167, 29-37. https://doi.org/10.1016/j.agwat.2015.12.021

Boari, F., Donadio, A., Schiattone, M.I., Cantore, V., 2015. Particle film technology: A supplemental tool to save water. Agric. Water Manag. 147, 154-162. https://doi.org/10.1016/j.agwat.2014.07.014

Bodner, G., Nakhforoosh, A., Kaul, H., 2015. Management of crop water under drought : a review. Agron. Sustain. Dev. 35, 401-442. https://doi.org/10.1007/s13593-015-0283-4

Bowen, P., Shellie, K.C., Mills, L., Willwerth, J., Bogdanoff, C., Keller, M., 2016. Abscisic acid form, concentration, and application timing influence phenology and bud cold hardiness in Merlot grapevines. Can. J. Plant Sci. 96, 347-359. https://doi.org/10.1139/cjps-2015-0257

Brahma, R., Janawade, A.D., Palled, Y.B., 2007. Effect of Irrigation Schedules , Mulch and Antitranspirant on Growth, Yield and Economics of Wheat. Karnataka J. Agric. Sci. 20(1) 20, 6-9.

Braun, D.M., Wang, L., Ruan, Y.L., 2014. Understanding and manipulating sucrose phloem loading, unloading, metabolism, and signalling to enhance crop yield and food security. J. Exp. Bot. 65, 1713-1735. https://doi.org/10.1093/jxb/ert416

Brillante, L., Belfiore, N., Gaiotti, F., Lovat, L., Sansone, L., Poni, S., Tomasi, D., 2016. Comparing kaolin and pinolene to improve sustainable grapevine 
production during drought. PLoS One 11, 1-19. https://doi.org/10.1371/journal.pone.0156631

Brito, C., Dinis, L., Moutinho-pereira, J., Correia, C., 2019. Scientia Horticulturae Kaolin , an emerging tool to alleviate the e ff ects of abiotic stresses on crop performance. Sci. Hortic. (Amsterdam). 250, 310-316. https://doi.org/10.1016/j.scienta.2019.02.070

Brito, C., Dinis, L.T., Ferreira, H., Rocha, L., Pavia, I., Moutinho-Pereira, J., Correia, C.M., 2018. Kaolin particle film modulates morphological, physiological and biochemical olive tree responses to drought and rewatering. Plant Physiol. Biochem. 133, 29-39. https://doi.org/10.1016/j.plaphy.2018.10.028

Brown, P., Saa, S., 2015. Biostimulants in agriculture. Front. Plant Sci. 6, 671. https://doi.org/https://doi.org/10.3389/fpls.2015.00671

Campolo, O., Romeo, F.V., Malacrinò, A., Laudani, F., Carpinteri, G., Fabroni, S., Rapisarda, P., Palmeri, V., 2014. Effects of inert dusts applied alone and in combination with sweet orange essential oil against Rhyzopertha dominica (Coleoptera: Bostrichidae) and wheat microbial population. Ind. Crops Prod. 61, 361-369. https://doi.org/10.1016/j.indcrop.2014.07.028

Cantore, V., Pace, B., Albrizio, R., 2009. Kaolin-based particle film technology affects tomato physiology, yield and quality. Environ. Exp. Bot. 66, 279-288. https://doi.org/10.1016/j.envexpbot.2009.03.008

Cao, M., Liu, X., Zhang, Y., Xue, X., Zhou, X.E., Melcher, K., Gao, P., Wang, F., 2013. An ABA-mimicking ligand that reduces water loss and promotes drought resistance in plants. Nat. Publ. Gr. 23, 1043-1054. https://doi.org/10.1038/cr.2013.95

Casey Barickman, T., Kopsell, D.A., Sams, C.E., 2014. Foliar applications of abscisic acid decrease the incidence of blossom-end rot in tomato fruit. Sci. Hortic. (Amsterdam). 179, 356-362. https://doi.org/10.1016/j.scienta.2014.10.004

Chamchaiyaporn, T., Jutamanee, K., Kasemsap, P., Vaithanomsat, P., Henpitak, C., 2013. Effects of kaolin clay coating on mango leaf gas exchange, fruit yield and quality. Kasetsart J. - Nat. Sci. 47, 479-491.

Conde, A., Pimentel, D., Neves, A., Dinis, L.T., Bernardo, S., Correia, C.M., Gerós, H., Moutinho-Pereira, J., 2016. Kaolin foliar application has a stimulatory effect on phenylpropanoid and flavonoid pathways in grape berries. Front. Plant Sci. 7, 1-14. https://doi.org/10.3389/fpls.2016.01150

Correia, C.M., Dinis, L.-T., Fraga, H., Pinheiro, R., Ferreira, H.M., Costa, J., Gonçalves, I., Oliveira, A.A., Pinto, G., Santos, J.A., Malheiro, A.C., MoutinhoPereira, J.M., 2015. Enhanced Yield and Physiological Performance of Mediterranean Grapevines through Foliar Kaolin Spray. Procedia Environ. Sci. 29, 247-248. https://doi.org/10.1016/j.proenv.2015.07.295

Cosic, M., Stricevic, R., Djurovic, N., Lipovac, A., Bogdan, I., Pavlovic, M., 2018. Effects of irrigation regime and application of kaolin on canopy temperatures of sweet pepper and tomato. Sci. Hortic. (Amsterdam). 238, 23-31. https://doi.org/10.1016/j.scienta.2018.04.035 
Cosic, M., Stricevic, R., Djurovic, N., Prokic, L., Marjanovic, M., Moravcevic, D., 2016. Impact of irrigation regime and application of kaolin on the stomatal conductance and leaf water potential of pepper and tomato. Agric. Mont. Cadastre Ser. 46, 92-100.

Cui, Z., Zhou, B., Zhang, Z., Hu, Z., 2013. Abscisic acid promotes flowering and enhances LcAP1 expression in Litchi chinensis Sonn. South African J. Bot. 88, 76-79. https://doi.org/10.1016/j.sajb.2013.05.008

D'Aquino, S., Cocco, A., Ortu, S., Schirra, M., 2011. Effects of kaolin-based particle fi Im to control Ceratitis capitata ( Diptera : Tephritidae ) infestations and postharvest decay in citrus and stone fruit. Crop Prot. 30, 1079-1086. https://doi.org/10.1016/j.cropro.2011.03.019

da Silva, P.S.O., de Oliveira Junior, L.F.G., de Mattos, E.C., dos Santos Maciel, L.B., dos Santos, M.P.F., Sena, E.D.O.A., Barbosa, N.T.B., Carnelossi, M.A.G., Fagundes, J.L., 2019. Calcium particle films promote artificial shading and photoprotection in leaves of American grapevines (Vitis labrusca $L$.). Sci. Hortic. (Amsterdam). 252, 77-84.

da Silva, Paulo Silas Oliveira, Oliveira, L.F.G., Silva Gonzaga, M.I., de Oliveira Alves Sena, E., dos Santos Maciel, L.B., Pinheiro Fiaes, M., de Mattos, E.C., Gutierrez Carnelossi, M.A., 2019. Effects of calcium particle films and natural shading on ecophysiological parameters of conilon coffee. Sci. Hortic. (Amsterdam). 245, 171-177. https://doi.org/10.1016/j.scienta.2018.10.010

Dami, I.E., Li, S., Bowen, P.A., Bogdanoff, C.P., Shellie, K.C., Willwerth, J., 2015. Foliar applied abscisic acid increases 'chardonnay' grapevine bud freezing tolerance during autumn cold acclimation. Horttechnology 25, 293-305. https://doi.org/10.21273/horttech.25.3.293

Das, V.S.., Raghavendra, A.., 1979. Antitranspirants for improvement of water use efficiency of crops. Outlook Agric. 10, 92-98.

Dass, A., Bhattacharyya, R., 2017. Wheat residue mulch and anti-transpirants improve productivity and quality of rainfed soybean in semi-arid north-Indian plains. F. Crop. Res. 210, 9-19. https://doi.org/10.1016/j.fcr.2017.05.011

Davenport, D.C., Fisher, M.A., Hagan, R.M., 1972. Some Counteractive Effects of Antitranspirants. Plant Physiol 49, 722-724.

De, R., Bhujanga Rao, D.V.S., Yogeswara Rao, Y., Giri Rao, L.G., Ikramullah, M., 1983. Modification of irrigation requirement of wheat through mulching and foliar application of transpiration suppressants. Irrig. Sci. 4, 215-223. https://doi.org/10.1007/BF00285527

De, R., Giri, G., 1978. Effect of mulching and kaolin foliar spray on mung ( Vigna radiata) - rapeseed ( Brassica campestris) double cropping system under rainfed conditions. J. Agric. Sci. 91, 191-197.

De Storme, N., Geelen, D., 2014. The impact of environmental stress on male reproductive development in plants: biological processes and molecular mechanisms. Plant. Cell Environ. 37, 1-18. https://doi.org/10.1111/pce.12142

del Amor, F.M., Cuadra-Crespo, P., Walker, D.J., Cámara, J.M., Madrid, R., 2010. Effect of foliar application of antitranspirant on photosynthesis and water relations of pepper plants under different levels of CO2and water stress. J. 
del Amor, F.M., Rubio, J.S., 2009. Effects of antitranspirant spray and potassium: Calcium: Magnesium ratio on photosynthesis, nutrient and water uptake, growth, and yield of sweet pepper. J. Plant Nutr. 32, 97-111. https://doi.org/10.1080/01904160802531043

Denaxa, N.K., Roussos, P.A., Damvakaris, T., Stournaras, V., 2012. Comparative effects of exogenous glycine betaine, kaolin clay particles and Ambiol on photosynthesis, leaf sclerophylly indexes and heat load of olive cv. Chondrolia Chalkidikis under drought. Sci. Hortic. (Amsterdam). 137, 87-94. https://doi.org/10.1016/j.scienta.2012.01.012

Desoky, E.M., Tohamy, M.R.A., Eisa, G.S.A., 2013. Effect of some antitranspirant substances on growth, yield and flag leaf structure of wheat plant( Triticum aestivum L .)grown under water stress conditions. Zagazig J. Agric. Res. 40, 223-233.

Di Stasio, E., Rouphael, Y., Raimondi, G., El-Nakhel, C., De Pascale, S., 2018. Postharvest performance of cut rose cv. Lovely red as affected by osmoprotec-tant and antitraspirant compounds. Adv. Hortic. Sci. 32, 311-318. https://doi.org/10.13128/ahs-22302

Dinis, L.T., Bernardo, S., Conde, A., Pimentel, D., Ferreira, H., Félix, L., Gerós, H., Correia, C.M., Moutinho-Pereira, J., 2016. Kaolin exogenous application boosts antioxidant capacity and phenolic content in berries and leaves of grapevine under summer stress. J. Plant Physiol. 191, 45-53. https://doi.org/10.1016/j.jplph.2015.12.005

Dinis, L.T., Bernardo, S., Luzio, A., Pinto, G., Meijón, M., Pintó-Marijuan, M., Cotado, A., Correia, C., Moutinho-Pereira, J., 2018. Kaolin modulates ABA and IAA dynamics and physiology of grapevine under Mediterranean summer stress. J. Plant Physiol. 220, 181-192. https://doi.org/10.1016/j.jplph.2017.11.007

Djurovic, N., Cosic, M., Stricevic, R., Savic, S., Domazet, M., 2016. Effect of irrigation regime and application of kaolin on yield, quality and water use efficiency of tomato. Sci. Hortic. (Amsterdam). 201, 271-278. https://doi.org/10.1016/j.scienta.2016.02.017

Dolferus, R., Ji, X., Richards, R.A., 2011. Abiotic stress and control of grain number in cereals. Plant Sci. 181, 331-341. https://doi.org/10.1016/j.plantsci.2011.05.015

Dunstone, R.L., Richards, R.A., Rawson, H.M., 1988. Variable responses of stomatal conductance, growth, and yield to fulvic acid applications to wheat. Aust. J. Agric. Res. 39, 547-553. https://doi.org/10.1071/AR9880547

El-azm, N.A.I.A., Youssef, S.M.S., 2015. Spraying potassium silicate and sugar beet molasses on tomato plants minimizes transpiration, relieves drought stress and rationalizes water use. Middle East J 4, 1047-1064.

El-Deen, T.N., Elbohy, N.F., Attia, K.E., Mokhtar, N.A.Y., 2018. Synergistic impact of soil mulching and kaolin concentration on Zinnia elegans plants grown under different irrigation levels. Bull. Fac. Agric. Cairo Univ. 69, 403-425. https://doi.org/10.1093/imamci/dnt037 
El-Khawaga, A.S., 2013. Response of grand naine banana plants grown under different soil moisture levels to antitranspirants application. Asian J. Crop Sci. 5, 238-250. https://doi.org/10.3923/ajcs.2013.238.250

El-Khawaga, A.S., Mansour, A.E.M., 2014. Enhancing the Efficiency of Irrigation Water Use by Using Some Antitranspirants in Wounderful Pomegranate Orchards. Middle East J. Agric. Res. 3, 694-700.

El-Said, E., 2015. Effect of Irrigation Intervals and Some Antitranspirants on Growth, Yield and Fruit Quality of Eggplant. J. Plant Prod. 6, 2079-2091. https://doi.org/10.21608/jpp.2015.52435

El-wafa, M.A., 2015. Effect of Some Treatments on Reducing Sunburn in Wonderful Pomegranate Fruit Trees. Egypt. J. Hortic. 42, 795-806

El Mantawy, R.F., El Bialy, M., 2018. Effect of antitranspirant application on growth and productivity of sunflower under soil moisture stress. Nat. Sci. 16, 92-106. https://doi.org/10.7537/marsnsj160218.15.Key

Fahey, D.J., Rogiers, S.Y., 2018. Di-1- p -menthene reduces grape leaf and bunch transpiration. Aust. J. grape wine Res. 25, 134-141. https://doi.org/10.1111/ajgw.12371

Fan, W., Li, J., Jia, J., Wang, F., Cao, C., Hu, J., Mu, Z., 2015. Pyrabactin regulates root hydraulic properties in maize seedlings by affecting PIP aquaporins in a phosphorylation-dependent manner. Plant Physiol. Biochem. 94, 28-34. https://doi.org/10.1016/j.plaphy.2015.05.005

Fanourakis, D., Giday, H., Li, T., Kambourakis, E., Ligoxigakis, E.K., Papadimitriou, M., Strataridaki, A., Bouranis, D., Fiorani, F., Heuvelink, E., Ottosen, C.O., 2016. Antitranspirant compounds alleviate the milddesiccation-induced reduction of vase life in cut roses. Postharvest Biol. Technol. 117, 110-117. https://doi.org/10.1016/j.postharvbio.2016.02.007

Faralli, M., Grove, I.G., Hare, M.C., Alcalde-Barrios, A., Williams, K.S., Corke, F.M.K., Kettlewell, P.S., 2017. Modulation of Brassica napus source-sink physiology through film antitranspirant induced drought tolerance amelioration that is dependent on the stress magnitude. J. Agron. Crop Sci. 203, 360-372. https://doi.org/10.1111/jac.12198

Faralli, M., Grove, I.G., Hare, M.C., Boyle, R.D., Williams, K.S., Corke, F.M.K., Kettlewell, P.S., 2016. Canopy application of film antitranspirants over the reproductive phase enhances yield and yield-related physiological traits of water-stressed oilseed rape (Brassica napus). Crop Pasture Sci. 67, 751765. https://doi.org/10.1071/CP15421

Faralli, Michele, Grove, I.G., Hare, M.C., Kettlewell, P.S., 2017. In-field film antitranspirant application shows potential yield protection from floweringstage drought periods in winter canola (Brassica napus). Crop Pasture Sci. 68, 243-253. https://doi.org/10.1071/CP16427

Farooq, M., Wahid, A., Kobayashi, N., Fujita, D., Basra, S.M.A., 2009. Plant drought stress : effects, mechanisms and management. Agron. Sustain. Dev. 29, 185-212.

Fayed, T.., El-mohsen, M.A.A., Ali, M.M., El-karim, M.S.A., 2018. Enhancing water use efficiency of "Le Conte" pear trees under deficit irrigation conditions. 
Ferrara, G., Mazzeo, A., Matarrese, A.M.S., Pacucci, C., Punzi, R., Faccia, M., Trani, A., Gambacorta, G., 2015. Application of abscisic acid (S-ABA) and sucrose to improve colour, anthocyanin content and antioxidant activity of cv. Crimson Seedless grape berries. Aust. J. Grape Wine Res. 21, 18-29. https://doi.org/10.1111/ajgw.12112

Ferrari, V., Disegna, E., Dellacassa, E., Coniberti, A., 2017. Influence of timing and intensity of fruit zone leaf removal and kaolin applications on bunch rot control and quality improvement of Sauvignon blanc grapes, and wines, in a temperate humid climate. Sci. Hortic. (Amsterdam). 223, 62-71. https://doi.org/10.1016/j.scienta.2017.05.034

Francini, A., Lorenzini, G., Nali, C., 2011. The antitranspirant Di-1-p-menthene, a potential chemical protectant of ozone damage to plants. Water. Air. Soil Pollut. 219, 459-472. https://doi.org/10.1007/s11270-010-0720-6

Fuehring, H.D., 1973. Effect of Antitranspirants on Yield of Grain Sorghum Under Limited Irrigation. Agron. J. 65, 348-351.

Fuehring, H.D., Finkner, M.D., 1983. Effect of Folicote Antitranspirant Application on Field Grain Yield of Moisture-Stressed Corn. Agron. J. 75, 579. https://doi.org/10.2134/agronj1983.00021962007500040003x

Gale, J., Hagan, R.M., 1966. Plant antitranspirants. Annu. Rev. Plant Physiol. 17, 269-282.

Gale, J., Poljakoff-Mayber, A., 1965. Effect of antitranspirant treatment on leaf temperatures. Plant Cell Physiol. 6, 111-115. https://doi.org/10.1093/oxfordjournals.pcp.a079076

Gatti, M., Galbignani, M., Garavani, A., Bernizzoni, F., Tombesi, S., Palliotti, A., Poni, S., 2016. Manipulation of ripening via antitranspirants in cv. Barbera (Vitis viniferaL.). Aust. J. Grape Wine Res. 22, 245-255. https://doi.org/10.1111/ajgw.12212

Gawad, N.M.A.A., 2015. Effect of Some Anti-transpirant to Reduce Amount of Irrigation Water Added to the Banana cv."Grand Nain" in Sandy Soil. Egypt. J. Hortic. 42, 69-86. https://doi.org/10.21608/ejoh.2014.1181

Geng, X.M., Li, M., Lu, L., Okubo, H., Ozaki, Y., 2015. ABA improves postharvest quality of Cut Lilium "Sorbonne" Harvested in Late Period. J. Fac. Agric. Kyushu Univ. 60, 81-86.

Ghaffari, H., Reza, M., Muhammad, T., Cheema, M., Razmjoo, J., 2019. Prolinemediated changes in antioxidant enzymatic activities and the physiology of sugar beet under drought stress. Acta Physiol. Plant. 41, 23. https://doi.org/10.1007/s11738-019-2815-z

Gharaghani, A., Mohammadi Javarzari, A., Vahdati, K., 2018. Kaolin particle film alleviates adverse effects of light and heat stresses and improves nut and kernel quality in Persian walnut. Sci. Hortic. (Amsterdam). 239, 35-40. https://doi.org/10.1016/j.scienta.2018.05.024

Gindaba, J., Wand, S.J.E., 2005. Comparative effects of evaporative cooling, kaolin particle film, and shade net on sunburn and fruit quality in apples. 
Glenn, D.M., 2016a. Effect of highly processed calcined kaolin residues on apple productivity and quality D.M. Sci. Hortic. (Amsterdam). 201, 101-108. https://doi.org/https://doi.org/10.1016/j.scienta.2016.01.035

Glenn, D.M., 2016b. Effect of highly processed calcined kaolin residues on apple water use efficiency. Sci. Hortic. (Amsterdam). 205, 127-132. https://doi.org/10.1016/j.scienta.2016.04.022

Glenn, D.M., 2010. Canopy Gas Exchange and Water Use Efficiency of \{'Empire'\} Apple in Response to Particle Film, Irrigation, and Microclimatic Factors. J. Am. Soc. Hortic. Sci. 135, 25-32.

Glenn, D.M., 2009. Particle Film Mechanisms of Action That Reduce the Effect of Environmental Stress in \{'Empire'\} Apple. J. Am. Soc. Hortic. Sci. 134, 314321. https://doi.org/10.1016/j.scienta.2015.02.030

Glenn, D.M., Puterka, G.J., 2005. Particle Films: A New Technology for Agriculture. Hortic. Rev. (Am. Soc. Hortic. Sci). 31, 1-44. https://doi.org/10.1002/9780470650882.ch1

Glenn, M.D., 2012. The mechanisms of plant stress mitigation by kaolin-based particle films and applications in horticultural and agricultural crops. HortScience 47, 710-711.

Gonzalez, R., Gonzalez, M.R., Martin, P., 2018. Abscisic acid and ethephon treatments applied to 'verdejo' white grapes affect the quality of wine in different ways. Sci. Agric. 75, 381-386. https://doi.org/10.1590/1678-992x2017-0177

Granger, A., Trager, D., 2002. Effect of pre-harvest applications of an antitranspirant and vegetable oil on cracking and size of cherry (Prunus avium L.) cv. Van fruit. Aust. J. Exp. Agric. 42, 93-96.

Gu, S., Jacobs, S., Du, G., 2011. Efficacy, rate and timing of applications of abscisic acid to enhance fruit anthocyanin contents in "Cabernet Sauvignon" grapes. J. Hortic. Sci. Biotechnol. 86, 505-510. https://doi.org/10.1080/14620316.2011.11512796

Han, S., Lee, Yeongmok, Park, E.J., Min, M.K., Lee, Yongsang, Kim, T.H., Kim, B.G., Lee, S., 2019. Structural determinants for pyrabactin recognition in ABA receptors in Oryza sativa. Plant Mol. Biol. https://doi.org/10.1007/s11103-01900862-6

Hebert, C.J., Lebude, A. V, Campbell, C., 2010. Effects of s-ABA on the Physiology and Marketability of Various Container-Grown Taxa During ShortTerm. J. Environ. Hortic. 28, 202-208.

Heller, K., Woznica, Z., Byczynska, M., Wielgusz, K., Baraniecki, P., 2013. The Efficacy of Salicylic and Acetylsalicylic Acids in the Protection of Fibrous Flax Against Drought Stress. J. Nat. Fibers 10, 29-39. https://doi.org/10.1080/15440478.2012.748298

Hidangmayum, A., Dwivedi, P., Katiyar, D., Hemantaranjan, A., 2019. Application of chitosan on plant responses with special reference to abiotic stress. Physiol. Mol. Biol. Plants 25, 313-326. https://doi.org/10.1007/s12298-018- 
Huang, X., Lin, S., He, S., Lin, X., Liu, J., Chen, R., Li, H., 2018. Characterization of stomata on floral organs and scapes of cut 'Real' gerberas and their involvement in postharvest water loss. Postharvest Biol. Technol. 142, 39-45. https://doi.org/10.1016/j.postharvbio.2018.04.001

Huang, Z., Hejazi, M., Tang, Q., Vernon, C.R., Liu, Y., Chen, M., Calvin, K., 2019. Global agricultural green and blue water consumption under future climate and land use changes. J. Hydrol. 574, 242-256. https://doi.org/10.1016/j.jhydrol.2019.04.046

Hunter, M.C., Smith, R.G., Schipanski, M.E., Atwood, L.W., Mortensen, D.A., 2017. Agriculture in 2050 : Recalibrating Targets for Sustainable Intensification 67, 386-391. https://doi.org/10.1093/biosci/bix010

IPCC, 2018. Impacts of $1.5^{\circ} \mathrm{C}$ of Global Warming on Natural and Human Systems [WWW Document]. Glob. Warm. $1.5^{\circ} \mathrm{C}$. An IPCC Spec. Rep. impacts Glob. Warm. $1.5^{\circ} \mathrm{C}$ above pre-industrial levels Relat. Glob. Greenh. gas Emiss. pathways, Context Strength. Glob. response to Threat Clim. Chang. URL https://www.ipcc.ch/sr15 (accessed 5.16.19).

Iriti, M., Picchi, V., Rossoni, M., Gomarasca, S., Ludwig, N., Gargano, M., Faoro, F., 2009. Chitosan antitranspirant activity is due to abscisic acid-dependent stomatal closure. Environ. Exp. Bot. 66, 493-500. https://doi.org/10.1016/j.envexpbot.2009.01.004

Iriti, M., Vitalini, S., Di Tommaso, G., D\&apos;Amico, S., Borgo, M., Faoro, F., 2011. New chitosan formulation prevents grapevine powdery mildew infection and improves polyphenol content and free radical scavenging activity of grape and wine. Aust. J. Grape Wine Res. 17, 263-269. https://doi.org/10.1111/j.1755-0238.2011.00149.x

Isa, H.M., Manga, A.A., Hussaini, M.A., 2017. Response of Tomato ( Solanum lycopersicon L .) to Antitranspirants and Moisture Stress in Kano, Sudan Savanna of Nigeria. J. Dryl. Agric. 3, 48-58.

Jager, K., Fabian, A., Barnabas, B., 2008. Effect of water deficit and elevated temperature on pollen development of drought sensitive and tolerant winter wheat (Triticum aestivum L.) genotypes. Acta Biol. Szeged. 52, 67-71.

Javan, M., Tajbakhsh, M., Mandoulakani, B.A., 2013. Effect of antitranspirants application on yield and yield components in soybean ( Glycine max L .) under limited irrigation 7, 70-74.

Jee, H.J., Shim, C.K., Ryu, K.Y., Park, J.H., Lee, B.M., Choi, D.H., Ryu, G.H., 2009. Control of powdery and downy mildews of cucumber by using cooking oils and yolk mixture. Plant Pathol. J. 25, 280-285.

Ji, X., Dong, B., Shiran, B., Talbot, M.J., Edlington, J.E., Hughes, T., White, R.G., Gubler, F., Dolferus, R., 2011. Control of Abscisic Acid Catabolism and Abscisic Acid Homeostasis Is Important for Reproductive Stage Stress Tolerance in Cereals. Plant Physiol. 156, 647-662. https://doi.org/10.1104/pp.111.176164

Ji, X., Shiran, B., Wan, J., Lewis, D.C., Jenkins, C.L.D., Condon, A.G., Richards, R.A., Dolferus, R., 2010. Importance of pre-anthesis anther sink strength for 
maintenance of grain number during reproductive stage water stress in wheat. Plant, Cell Environ. 33, 926-942. https://doi.org/10.1111/j.13653040.2010.02130.x

Jia, H., Wang, S., Lin, H., Satio, T., Ampa, K., Todoroki, Y., Kondo, S., 2018. Effects of abscisic acid agonist or antagonist applications on aroma volatiles and anthocyanin biosynthesis in grape berries. J. Hortic. Sci. Biotechnol. 93, 392-399. https://doi.org/10.1080/14620316.2017.1379364

Katayama-Ikegami, A., Sakamoto, T., Shibuya, K., Katayama, T., Gao-Takai, M., 2016. Effects of Abscisic Acid Treatment on Berry Coloration and Expression of Flavonoid Biosynthesis Genes in Grape. Am. J. Plant Sci. 07, 1325-1336. https://doi.org/10.4236/ajps.2016.79127

Kato, Y., Kamoshita, A., Yamagishi, J., 2008. Preflowering abortion reduces spikelet number in upland rice (Oryza sativa L.) under water stress. Crop Sci. 48, 2389-2395. https://doi.org/10.2135/cropsci2007.11.0627

Kawai, Y., Okamoto, M., Shiraishi, R., Fujisawa, H., 2014. Effects of Soil Application of the Naturally Occurring Form of Abscisic acid (S-ABA) on Development and Quality of Satsuma Mandarin Fruit. J. Agric. Sci. Tokyo Nogyo Daigaku 59, 114-120.

Kazemi, M., Abdossi, V., Kalateh Jari, S., Ladan Moghadam, A.R., 2017. Effect of pre- and postharvest salicylic acid treatment on physio-chemical attributes in relation to the vase life of cut rose flowers. J. Hortic. Sci. Biotechnol. 93, 8190. https://doi.org/10.1080/14620316.2017.1344571

Kettlewell, P., 2011. Economics of film antitranspirant application : a new approach to protecting wheat crops from drought-induced yield loss. Int. J. Agric. Manag. 1, 43-45.

Kettlewell, P.S., 2014. Waterproofing wheat - a re-evaluation of film antitranspirants in the context of reproductive drought physiology. Outlook Agric. 43, 25-29. https://doi.org/10.5367/oa.2014.0156

Kettlewell, P.S., Heath, W.L., Haigh, I.M., 2010. Yield enhancement of droughted wheat by film antitranspirant application: rationale and evidence. Agric. Sci. 01, 143-147. https://doi.org/10.4236/as.2010.13017

Kettlewell, P.S., Holloway, J.R., 2010. Connecting developmental and process physiology to improve yield of droughted wheat with a film antitra nspirant. Asp. Appl. Biol. 105, 23-24.

Khaleghi, E., Arzani, K., Moallemi, N., Barzegar, M., 2015. The efficacy of kaolin particle film on oil quality indices of olive trees (Olea europaea L.) cv "Zard" grown under warm and semi-arid region of Iran. Food Chem. 166, 35-41. https://doi.org/10.1016/j.foodchem.2014.06.006

Khalel, A. M. S., 2015. Effect of Drip Irrigation Intervals and Some Antitranspirants on the Water Status, Growth and Yield of Potato (Solanum tuberosum L.). J. Agric. Sci. Technol. B 5, 15-23. https://doi.org/10.17265/21616264/2015.01.002

Khalil, S.E., Hussein, M.M., Teixeira, J.A., 2012. Roles of Antitranspirants in Improving Growth and Water Relations of Jatropha curcas L . Grown under Water Stress Conditions. 
Khan, W., Rayirath, U.P., Subramanian, S., Jithesh, M.N., Rayorath, P., Hodges, D.M., Critchley, A.T., Craigie, J.S., Orrie, J., Prithiviraj, B., 2009. Seaweed Extracts as Biostimulants of Plant Growth and Development. J. Plant Growth Regul. 28, 386-399.

Kim, J., Malladi, A., Van lersel, M.W., 2012. Physiological and molecular responses to drought in Petunia: The importance of stress severity. J. Exp. Bot. https://doi.org/10.1093/jxb/ers285

Klucakova, M., 2018. Size and Charge Evaluation of Standard Humic and Fulvic Acids as Crucial Factors to Determine Their Environmental Behavior and Impact. Front. Chem. 6, 1-8. https://doi.org/10.3389/fchem.2018.00235

Klucakova, M., Pelikan, P., Lapcik, L., Lapcikova, B., Kucerik, J., Kalab, M., 2000. Structure and properties of humic and fulvic acids. I. Properties and reactivity of humic acids and fulvic acids. J. Polym. Mater. 17, 337-356.

Knight, I.A., Rains, G.C., Culbreath, A.K., Toews, M.D., 2017. Thrips counts and disease incidence in response to reflective particle films and conservation tillage in cotton and peanut cropping systems. Entomol. Exp. Appl. 162, 1929. https://doi.org/10.1111/eea.12523

Kok, D., Bal, E., 2018a. Leaf Removal Treatments Combined with Kaolin Particle Film Technique from Different Directions of Grapevine's Canopy Affect the Composition of Phytochemicals of cv. Muscat Hamburg (V. Vinifera L.). Erwerbs-Obstbau 60, 39-45. https://doi.org/10.1007/s10341-017-0337-7

Kok, D., Bal, E., 2018b. Enhancing Skin Color and Phenolic Compounds of Cv. Red Globe Table Grape (V. Vinifera L.) Utilizing of Different Preharvest Treatments. Erwerbs-Obstbau 60, 75-81. https://doi.org/https://doi.org/10.1007/s10341-017-0352-8

Koonjul, P.K., Minhas, J.S., Nunes, C., Sheoran, I.S., Saini, H.S., 2005. Selective transcriptional down-regulation of anther invertases precedes the failure of pollen development in water-stressed wheat. J. Exp. Bot. 56, 179-190. https://doi.org/10.1093/jxb/eri018

Kostka and Aquatrols Corporation of America, 2018. Systemic mitigation of environmental stress on plants and the fruit thereof. U.S. Patent 9,980,485.

Koyama, R., de Assis, A.M., Yamamoto, L.Y., Borges, W.F., Sá Borges, R. de, Prudêncio, S.H., Roberto, S.R., 2014. Exogenous abscisic acid increases the anthocyanin concentration of berry and juice from "Isabel" grapes (Vitis labrusca L.). HortScience 49, 460-464. https://doi.org/10.21273/hortsci.49.4.460

Koyama, R., Roberto, S.R., de Souza, R.T., Borges, W.F.S., Anderson, M., Waterhouse, A.L., Cantu, D., Fidelibus, M.W., Blanco-Ulate, B., 2018. Exogenous Abscisic Acid Promotes Anthocyanin Biosynthesis and Increased Expression of Flavonoid Synthesis Genes in Vitis vinifera $\times$ Vitis labrusca Table Grapes in a Subtropical Region. Front. Plant Sci. 9, 1-12. https://doi.org/10.3389/fpls.2018.00323

Kumar, K., Kumar, Y., Katiyar, N.K., 2018. Effect of plant geometry , nitrogen level and antitranspirants on physiological growth, yield attributes, WUE and economics of mustard ( Brassica juncea ) under semi-arid conditions of 
Kumar, M., Singh, V.P., Arora, A., Singh, N., 2014. The role of abscisic acid (ABA) in ethylene insensitive Gladiolus (Gladiolus grandiflora Hort.) flower senescence. Acta Physiol. Plant. 36, 151-159. https://doi.org/10.1007/s11738-013-1395-6

Latocha, P., Ciechocinska, M., Pietkiewicz, S., Kalaji, M., 2009. Preliminary assessment of antitranspirant Vapor Gard influence on Actinidia arguta growing under drought stress conditions. Ann. Warsaw Univ. Life Sci. SGGW. Hortic. Landsc. Archit. 30.

Lee, S.C., Luan, S., 2012. ABA signal transduction at the crossroad of biotic and abiotic stress responses. Plant, Cell Environ. 35, 53-60. https://doi.org/10.1111/j.1365-3040.2011.02426.x

Li, J., Wu, Y., Xie, Q., Gong, Z., 2017. Abscisic acid, in: Hormone Metabolism and Signaling in Plants. Academic, New York, p. pp.161-89. https://doi.org/10.1016/B978-0-12-811562-6.00005-0

Li, S., Dami, I.E., 2016. Responses of Vitis vinifera 'Pinot gris' Grapevines to Exogenous Abscisic Acid (ABA): I. Yield, Fruit Quality, Dormancy, and Freezing Tolerance. J. Plant Growth Regul. 35, 245-255. https://doi.org/10.1007/s00344-015-9529-2

Li, Y., Zhao, H., Duan, B., Korpelainen, H., Li, C., 2011. Effect of drought and ABA on growth, photosynthesis and antioxidant system of Cotinus coggygria seedlings under two different light conditions. Environ. Exp. Bot. 71, 107-113. https://doi.org/10.1016/j.envexpbot.2010.11.005

Li, Z., Zhang, Y., Zhang, X., Merewitz, E., Peng, Y., Ma, X., Huang, L., Yan, Y., 2017. Metabolic Pathways Regulated by Chitosan Contributing to Drought Resistance in White Clover. J. Proteome Res. 16, 3039-3052. https://doi.org/10.1021/acs.jproteome.7b00334

Liu, H., Searle, I.R., Mather, D.E., Able, A.J., Able, J.A., 2015. Morphological, physiological and yield responses of durum wheat to pre-anthesis waterdeficit stress are genotype-dependent. Crop Pasture Sci. 66, 1024-1038. https://doi.org/10.1071/CP15013

Lobos, G.A., Acevedo-opazo, C., Guajardo-moreno, A., Valdés-gómez, H., Taylor, J.A., Laurie, V.F., 2015. effects of kaolin on Cab.Sauv.grapevine physiology and fruit quality. J. Int. Sci. Vigne Vin 49, 137-144.

Lotfi, R., Pessarakli, M., Gharavi-Kouchebagh, P., Khoshvaghti, H., 2015. Physiological responses of Brassica napus to fulvic acid under water stress: Chlorophyll a fluorescence and antioxidant enzyme activity. Crop J. 3, 434439. https://doi.org/10.1016/j.cj.2015.05.006

Ludwig, N., Cabrini, R., Faoro, F., Gargano, M., Gomarasca, S., Iriti, M., Picchi, V., Soave, C., 2010. Reduction of evaporative flux in bean leaves due to chitosan treatment assessed by infrared thermography. Infrared Phys. Technol. 53, 65-70. https://doi.org/10.1016/j.infrared.2009.08.008

Lukic, I., Stricevic, R., Đurovic, N., Cosic, M., 2012. Tomato Water Use Efficiency, in: International Conference on Water, Climate \& Environment, , Ohrid, Makedonija (Vol. 28). BALWOIS, Ohrid, pp. 1-10. 
Luo, L.J., 2010. Breeding for water-saving and drought-resistance rice (WDR) in China. J. Exp. Bot. 61, 3509-3517. https://doi.org/10.1093/jxb/erq185

Lurie, S., Ovadia, R., Nissim-Levi, A., Oren-Shamir, M., Kaplunov, T., Zutahy, Y., Weksler, H., Lichter, A., 2009. Abscisic acid improves colour development in "Crimson Seedless" grapes in the vineyard and on detached berries. J. Hortic. Sci. Biotechnol. 84, 639-644. https://doi.org/10.1080/14620316.2009.11512579

Ma, D., Sun, D., Wang, C., Qin, H., 2015. Silicon Application Alleviates Drought Stress in Wheat Through Transcriptional Regulation of Multiple Antioxidant Defense Pathways. https://doi.org/10.1007/s00344-015-9500-2

Marko, V., Blommers, L.H.M., Bogya, S., Helsen, H., 2008. Kaolin particle films suppress many apple pests, disrupt natural enemies and promote woolly apple aphid. J. Appl. Entomol. 132, 26-35. https://doi.org/10.1111/j.14390418.2007.01233.x

McArtney, S.J., Abrams, S.R., Woolard, D.D., Petracek, P.D., 2014. Effects of Sabscisic acid and (+)-8'-acetylene abscisic acid on fruit set and stomatal conductance in apple. HortScience 49, 763-768. https://doi.org/10.21273/hortsci.49.6.763

Mcgrath, J.M., Lobell, D.B., 2013. Reduction of transpiration and altered nutrient allocation contribute to nutrient decline of crops grown in elevated $\mathrm{CO} 2$ concentrations. Plant, Cell Environ. 36, 697-705. https://doi.org/10.1111/pce.12007

Medina, V., Gilbert, M.E., 2015. Physiological trade-offs of stomatal closure under high evaporative gradients in fi eld grown soybean. Funct. plant Biol. 43, 4051.

Michael Glenn, D., Cooley, N., Walker, R., Clingeleffer, P., Shellie, K., 2010. Impact of kaolin particle film and water deficit on wine grape water use efficiency and plant water relations. HortScience 45, 1178-1187. https://doi.org/10.21273/hortsci.45.8.1178

Mikiciuk, G., Mikiciuk, M., Ptak, P., 2015. The effects of anitranspirant di-1-pmenthene on some physiological traits of strawberry. J. Ecol. Eng. 16, 161167. https://doi.org/10.12911/22998993/59366

Mikiciuk, G., Mozdzer, E., Mikiciuk, M., Chełpiński, P., 2013. The effect of antitranspirant on the content of microelements and trace elements in sweet cherry leaves and fruits. J. Ecol. Eng. 14, 36-38. https://doi.org/10.5604/2081139X.1066229

Miranda, M.P., Zanardi, O.Z., Tomaseto, A.F., Volpe, H.X.L., Garcia, R.B., Prado, E., 2018. Processed kaolin affects the probing and settling behavior of Diaphorina citri (Hemiptera: Lividae). Pest Manag. Sci. 74, 1964-1972. https://doi.org/10.1002/ps.4901

Moftah, A.E., Al-humaid, A.I., 2005. Effects of Kaolin and Pinolene Film-forming Polymers on Water Relations and Photosynthetic Rate of Tuberose ( Polianthes tuberosa L .). Agric. Sci. 18, 35-49.

Mohawesh, O.E., Al-Absi, K.M., Tadros, M.J., 2010. Effect of antitranspirant application on physiological and biochemical parameters of three orange 

cultivars grown under progressive water deficit. Adv. Hortic. Sci. 24, 183-194.

Moradi, P., Pasari, B., Fayyaz, F., 2017. The effects of fulvic acid application on seed and oil yield of safflower cultivars. J. Cent. Eur. Agric. 18, 584-597. https://doi.org/10.5513/JCEA01/18.3.1933

Munemasa, S., Hauser, F., Park, J., Waadt, R., Brandt, B., Schroeder, J.I., 2015. Mechanisms of abscisic acid-mediated control of stomatal aperture. Curr. Opin. Plant Biol. 28, 154-162. https://doi.org/10.1080/10937404.2015.1051611.INHALATION

Mupambi, G., Reynolds, J.S., Steyn, W.J., 2014. Foliar S-ABA application does not reduce sunburn in "Granny Smith" apple. Acta Hortic. 1042, 303-309. https://doi.org/10.17660/ActaHortic.2014.1042.36

Nandi, S., 1985. Studies on the cytogenetic effect of some mercuric fungicides. Cytologia (Tokyo). 50, 921-926.

Nateghi, M., Paknejad, F., Moarefi, M., 2013. Effect of Concentrations and Time of Kaolin Spraying on Wheat Aphid. J. Biol. Environ. Sci. 7, 163-168.

Nawaz, F., Ahmad, R., Waraich, E.A., Naeem, M.S., Shabbir, R.N., 2012. Nutrient uptake, physiological responses, and yield attributes of wheat (triticum aestivum I.) exposed to early and late drought stress. J. Plant Nutr. 35, 961974. https://doi.org/10.1080/01904167.2012.663637

Neto, F. J. D., Adilson, P.J., Daniel, C., Silvia, R.C., Fernando, F.P., Giuseppina, P.P.L., Renata, K., Sergio, R.R., Marco, A.T., 2017. Post-harvest conservation of Rubi grapes treated with abscisic acid. African J. Biotechnol. 16, 1758-1763. https://doi.org/10.5897/ajb2017.16134

Neto, Francisco José Domingues, Tecchio, M.A., Junior, A.P., Vedoato, B.T.F., Lima, G.P.P., Roberto, S.R., 2017. Effect of ABA on colour of berries, anthocyanin accumulation and total phenolic compounds of "Rubi" table grape (Vitis vinifera). Aust. J. Crop Sci. 11, 199-205. https://doi.org/10.21475/ajcs.17.11.02.p269

Noreen, S., Ashraf, M., Akram, N.A., 2011. Does exogenous application of salicylic acid improve growth and some key physiological attributes in sunflower plants subjected to salt stress? J. Appl. Bot. Food Qual. 84, 169177.

Nunez-Lopez, D.C., Ramirez-Godoy, A., Restrepo-Diaz, H., 2015. Impact of kaolin particle film and synthetic insecticide applications on whitefly populations Trialeurodes vaporariorum (Hemiptera: Aleyrodidae) and physiological attributes in bean (Phaseolus vulgaris) crop. HortScience 50, 1503-1508. https://doi.org/10.21273/hortsci.50.10.1503

Oh, H.D., Yu, D.J., Chung, S.W., Chea, S., Lee, H.J., 2018. Abscisic acid stimulates anthocyanin accumulation in 'Jersey' highbush blueberry fruits during ripening. Food Chem. 244, 403-407. https://doi.org/10.1016/j.foodchem.2017.10.051

Olivares, D., Contreras, C., Muñoz, V., Rivera, S., González-Agüero, M., Retamales, J., Defilippi, B.G., 2017. Relationship among color development, anthocyanin and pigment-related gene expression in 'Crimson Seedless' grapes treated with abscisic acid and sucrose. Plant Physiol. Biochem. 115, 
Onyemaobi, I., Liu, H., Siddique, K.H.M., Yan, G., 2017. Both Male and Female Malfunction Contributes to Yield Reduction under Water Stress during Meiosis in Bread Wheat. Front. Plant Sci. 7.

Ouerghi, F., Ben-Hammouda, M., Teixeira Da Silva, J.A., Albouchi, A., Bouzaien, G., Aloui, S., Cheikh-M'hamed, H., Nasraoui, B., 2014. The Effects of Vapor Gard on some Physiological Traits of Durum Wheat and Barley Leaves under Water Stress. Agric. Conspec. Sci. 79, 261-267.

Padmalatha, K., Weksler, H., Mugzach, A., Acheampong, A.K., Zheng, C., HalalyBasha, T., Or, E., 2017. ABA application during flowering and fruit set reduces berry number and improves cluster uniformity. Am. J. Enol. Vitic. 68, 275282. https://doi.org/10.5344/ajev.2017.16079

Page, T., Awarau, W., 2012. Performance of agarwood (Aquilaria crassna) seedling transplants improved by shade and fertiliser. For. Ecol. Manage. 265, 258-269. https://doi.org/10.1016/j.foreco.2011.10.041

Palliotti, A., Panara, F., Famiani, F., Sabbatini, P., Howell, G.S., Silvestroni, O., Poni, S., 2013. Postveraison application of antitranspirant di-1-p-menthene to control sugar accumulation in sangiovese grapevines. Am. J. Enol. Vitic. 64, 378-385. https://doi.org/10.5344/ajev.2013.13015

Palliotti, A., Poni, S., Berrios, J.G., Bernizzoni, F., 2010. Vine performance and grape composition as affected by early-season source limitation induced with anti-transpirants in two red Vitis vinifera L. cultivars. Aust. J. Grape Wine Res. 16, 426-433. https://doi.org/10.1111/j.1755-0238.2010.00103.x

Pandey, P.P., Sharma, R., Neelkanthe, S.S., 2017. Climate change: combating drought with antitranspirants and super absorbent. Plant Arch. 17, 11461156.

Pang, J., Turner, N.C., Khan, T., Du, Y., Xiong, J., Colmer, T.D., Devilla, R., Stefanova, K., Siddique, K.H.M., 2017. Response of chickpea ( Cicer arietinum $\mathrm{L}$.) to terminal drought : leaf stomatal conductance, pod abscisic acid concentration, and seed set. J. Exp. Bot. 68, 1973-1985. https://doi.org/10.1093/jxb/erw153

Panicker, G.K., Matta, F.B., 2016. Effect of abscisic acid and paclobutrazol on cold hardiness of rabbiteye blueberry (Vaccinium ashei Reade). Acta Hortic. 1117, 315-320. https://doi.org/10.17660/ActaHortic.2016.1117.51

Park, S., Mills, S.A., Moon, Y., Waterland, N.L., 2016. Evaluation of antitranspirants for enhancing temporary water stress tolerance in bedding plants. Horttechnology 26, 444-452.

Park, S.Y., Fung, P., Nishimura, N., Jensen, D.R., Fujii, H., Zhao, Y., Lumba, S., Santiago, J., Rodrigues, A., Chow, T.F.F., Alfred, S.E., Bonetta, D., Finkelstein, R., Provart, N.J., Desveaux, D., Rodriguez, P.L., McCourt, P., Zhu, J.K., Schroeder, J.I., Volkman, B.F., Cutler, S.R., 2009. Abscisic acid inhibits type $2 \mathrm{C}$ protein phosphatases via the PYR/PYL family of START proteins. Science (80-. ). 324, 1068-1071. https://doi.org/10.1126/science.1173041

Pascual, S., Cobos, G., Seris, E., González-Núñez, M., 2010. Effects of processed 
kaolin on pests and non-target arthropods in a Spanish olive grove. J. Pest Sci. (2004). 83, 121-133. https://doi.org/10.1007/s10340-009-0278-5

Patane, C., Pellegrino, A., DI Silvestro, I., 2018. Effects of calcium carbonate application on physiology, yield and quality of field-grown tomatoes in a semiarid Mediterranean climate. Crop Pasture Sci. 69, 411-418. https://doi.org/10.1071/CP17424

Patil, B.B., De, R., 1978. Studies on the effect of nitrogen fertilizer, row spacing and use of antitranspirants on rapeseed (Brassica campestris) grown under dryland conditions. J. Agric. Sci. UK 91, 257-264.

Patil, M.D., Dhindwal, A.S., Rajanna, G.A., 2014. Integrated moisture stress management in wheat (Triticum aestivum). Indian J. Agron. 59, 629-633.

Percival, G.C., Boyle, S., 2009. Evaluation of film forming polymers to control apple scab (Venturia inaequalis (Cooke) G. Wint.) under laboratory and field conditions. Crop Prot. 28, 30-35. https://doi.org/10.1016/j.cropro.2008.08.005

Pettit, R.E., 2004. Organic matter, humus, humate, humic acid, fulvic acid and humin: their importance in soil fertility and plant health [WWW Document]. CTI Res. URL http://www.harvestgrow.com/.pdf web site/Humates General Info.pdf (accessed 6.20.19).

Plaut, Z., Magril, Y., Kedem, U., 2004. A new film forming material, which reduces water vapour conductance more than CO2fixation in several horticultural crops. J. Hortic. Sci. Biotechnol. 79, 528-532. https://doi.org/10.1080/14620316.2004.11511800

Pompodakis, N.E., Terry, L.A., Joyce, D.C., Papadimitriou, M.D., Lydakis, D.E., Darras, A.I., 2010. Effects of storage temperature and abscisic acid treatment on the vase-life of cut "First Red" and "Akito" roses. J. Hortic. Sci. Biotechnol. 85, 253-259. https://doi.org/10.1080/14620316.2010.11512664

Prager, S.M., Vaughn, K., Lewis, M., Nansen, C., 2013. Oviposition and leaf probing by Bactericera cockerelli (Homoptera: Psyllidae) in response to a limestone particle film or a plant growth regulator applied to potato plants. Crop Prot. 45, 57-62.

Puli, M.R., Raghavendra, A.S., 2012. Pyrabactin , an ABA agonist, induced stomatal closure and changes in signalling components of guard cells in abaxial epidermis of Pisum sativum 63, 1349-1356. https://doi.org/10.1093/jxb/err364

Racsko, J., Marmor, F., Hopkins, C.R., Petracek, P., Silverman, F.P., Fritts, R., Liu, X., Woolard, D., Lopez, J., Leep, D., Pienaar, J., 2014. Use of S-abscisic acid (ConTego ${ }^{\mathrm{TM}} \mathrm{SL}$ ) in vegetable production. Acta Hortic. 1042, 243-253. https://doi.org/10.17660/ActaHortic.2014.1042.30

Raghavan, V., 1988. Anther and Pollen Development in Rice ( Oryza Sativa ). Am. J. Bot. 75, 183-196.

Ramírez-Godoy, A., Puentes-Peréz, G., Restrepo-Díaz, H., 2018. Evaluation of the effect of foliar application of kaolin clay and calcium carbonate on populations of Diaphorina citri (Hemiptera: Liviidae) in Tahiti lime. Crop Prot. 109, 62-71. https://doi.org/10.1016/j.cropro.2018.01.012 
Reddy, A.N., Sharma, R., Sravani, M., 2018. Impact of Different Levels of Irrigation and Antitranspirant upon Wheat (Triticum aestivum L.) PhysioBiochemical and Economical Yield under Soil Application of Hydrogel. Int. J. Curr. Microbiol. Appl. Sci. 7, 3361-3368. https://doi.org/10.20546/ijcmas.2018.709.417

Rehman, M., Singh, Z., Khurshid, T., 2018. Scientia Horticulturae Pre-harvest spray application of abscisic acid ( S-ABA ) regulates fruit colour development and quality in early maturing M7 Navel orange. Sci. Hortic. (Amsterdam). 229, 1-9. https://doi.org/10.1016/j.scienta.2017.10.012

Roussos, P.A., Denaxa, N.K., Damvakaris, T., Stournaras, V., Argyrokastritis, I., 2010. Effect of alleviating products with different mode of action on physiology and yield of olive under drought. Sci. Hortic. (Amsterdam). 125, 700-711. https://doi.org/10.1016/j.scienta.2010.06.003

Ruan, Y.L., Jin, Y., Yang, Y.J., Li, G.J., Boyer, J.S., 2010. Sugar input, metabolism, and signaling mediated by invertase: Roles in development, yield potential, and response to drought and heat. Mol. Plant 3, 942-955. https://doi.org/10.1093/mp/ssq044

Sanbagavalli, S., Vaiyapuri, K., Marimuthu, S., 2017. Impact of mulching and antitranspirants on growth and yield of soybean (Glycine max L. Merril). Adv. Environ. Biol. 11, 84-89.

Sandhu, A.K., Gray, D.J., Lu, J., Gu, L., 2011. Effects of exogenous abscisic acid on antioxidant capacities, anthocyanins, and flavonol contents of muscadine grape (Vitis rotundifolia) skins. Food Chem. 126, 982-988. https://doi.org/10.1016/j.foodchem.2010.11.105

Santos, B.M., Salame-Donoso, T.P., Whidden, A.J., 2012. Reducing sprinkler irrigation volumes for strawberry transplant establishment in Florida. Horttechnology 22, 224-227. https://doi.org/10.21273/horttech.22.2.224

Saradadevi, R., Palta, J.A., Siddique, K.H.M., 2017. ABA-Mediated Stomatal Response in Regulating Water Use during the Development of Terminal Drought in Wheat. Front. Plant Sci. 8, 1-14. https://doi.org/10.3389/fpls.2017.01251

Schrader, L.E., 2011. Scientific basis of a unique formulation for reducing sunburn of fruits. HortScience 46, 6-11.

Segura-Monroy, S., Uribe-Vallejo, A., Ramirez-Godoy, A., Restrepo-Diaz, H., 2015. Effect of kaolin application on growth, water use efficiency, and leaf epidermis characteristics of Physalis peruviana L. seedlings under two irrigation regimes. J. Agric. Sci. Technol. 17, 1585-1596.

Sharma, R.R., Datta, S.C., Varghese, E., 2018. Effect of Surround WP®, a kaolinbased particle film on sunburn, fruit cracking and postharvest quality of 'Kandhari' pomegranates. Crop Prot. 114, 18-22. https://doi.org/10.1016/j.cropro.2018.08.009

Shavrukov, Y., Kurishbayev, A., Jatayev, S., Shvidchenko, V., Zotova, L., Koekemoer, F., de Groot, S., Soole, K., Langridge, P., 2017. Early Flowering as a Drought Escape Mechanism in Plants: How Can It Aid Wheat Production? Front. Plant Sci. 8, 1-8. https://doi.org/10.3389/fpls.2017.01950 
Shellie, K.C., King, B.A., 2013. Kaolin particle film and water deficit influence red winegrape color under high solar radiation in an arid climate. Am. J. Enol. Vitic. 64, 214-222. https://doi.org/10.5344/ajev.2013.12067

Shi, T.Q., Peng, H., Zeng, S.Y., Ji, R.Y., Shi, K., Huang, H., Ji, X.J., 2017. Microbial production of plant hormones: Opportunities and challenges. Bioengineered 8, 124-128. https://doi.org/10.1080/21655979.2016.1212138

Shimizu-Yumoto, H., Ichimura, K., 2009. Abscisic acid, in combination with sucrose, is effective as a pulse treatment to suppress leaf damage and extend foliage vase-life in cut Eustoma flowers. J. Hortic. Sci. Biotechnol. 84, 107-111. https://doi.org/10.1080/14620316.2009.11512489

Shinohara, T., Leskovar, D.I., 2014. Effects of ABA, antitranspirants, heat and drought stress on plant growth, physiology and water status of artichoke transplants. Sci. Hortic. (Amsterdam). https://doi.org/10.1016/j.scienta.2013.10.045

Silva, C.A.D., Ramalho, F.S., 2013. Kaolin spraying protects cotton plants against damages by boll weevil Anthonomus grandis Boheman (Coleoptera: Curculionidae). J. Pest Sci. (2004). 86, 563-569. https://doi.org/10.1007/s10340-013-0483-0

Sinclair, T.R., Bingham, G.E., Lemon, E.R., Allen, L.H., 1975. Water Use Efficiency of Field-grown Maize during Moisture Stress. Plant Physiol. 56, 245-249. https://doi.org/10.1104/pp.56.2.245

Singh, A.S., Sharma, R., Burondkar, S.S., Dubey, S., 2018. Efficacy of Pusa Hydrogel and Chitosan on Wheat (Triticum aestivum L.) Growth and Yield under Water Deficit Condition. Int. J. Curr. Microbiol. Appl. Sci. 7, 3064-3071. https://doi.org/10.20546/ijcmas.2018.709.382

Singh, K., Mcclean, C.J., Büker, P., Hartley, S.E., Hill, J.K., 2017. Mapping regional risks from climate change for rainfed rice cultivation in India. Agric. Syst. 156, 76-84. https://doi.org/10.1016/j.agsy.2017.05.009

Singh, S., Arora, N.K., Gill, M.I.S., Gill, K.S., 2016. Pre-harvest application of abscisic acid improves the fruit quality of flame seedless grapes (Vitis vinifera I.). The Bioscan 11, 1351-1355.

Solarova, J., Pospisilova, J., Slavik, B., 1981. Gas exchange regulation by changing of epidermal conductance with antitranspirants. Photosynthetica 15, 365-400.

Song, J., Shellie, K.C., Wang, H., Qian, M.C., 2012. Influence of deficit irrigation and kaolin particle film on grape composition and volatile compounds in Merlot grape (Vitis vinifera L.). Food Chem. 134, 841-850. https://doi.org/10.1016/j.foodchem.2012.02.193

Sootahar, M.K., Zeng, X., Su, S., Wang, Y., Bai, L., 2019. molecules The E ff ect of Fulvic Acids Derived from Di ff erent Materials on Changing Properties of Albic Black Soil in the Northeast Plain of China. Molecules 24, 1-12.

Sreenivasulu, N., Harshavardhan, V.T., Govind, G., Seiler, C., Kohli, A., 2012. Contrapuntal role of ABA: Does it mediate stress tolerance or plant growth retardation under long-term drought stress? Gene 506, 265-273. https://doi.org/10.1016/j.gene.2012.06.076 
Tacoli, F., Mori, N., Pozzebon, A., Cargnus, E., Da Vià, S., Zandigiacomo, P., Duso, C., Pavan, F., 2017a. Control of scaphoideus titanus with natural products in organic vineyards. Insects 8, 1-10. https://doi.org/10.3390/insects8040129

Tacoli, F., Pavan, F., Cargnus, E., Tilatti, E., Pozzebon, A., Zandigiacomo, P., 2017b. Efficacy and Mode of Action of Kaolin in the Control of Empoasca vitis and Zygina rhamni (Hemiptera: Cicadellidae) in Vineyards. J. Econ. Entomol. 110, 1164-1178. https://doi.org/10.1093/jee/tox105

Tepkaew, T., Duangsrisai, S., Vaithanomsat, P., Jutamanee, K., 2014. Photosynthetic performance, carbohydrate contents and yield affected by kaolin particle film application in grape, in: The International Bioscience Conference and the 5th Joint International PSU-UNS Bioscience. Phuket, pp. 61-65.

Thorat, D., Tandel, Y., Thakriya, H., 2018. Effect of antitranspirants on growth and survival of epicotyl grafts of mango (Mangifera indica L.) Cv. kesar. Int. J. Chem. Stud. 6, 29-31.

Travaglia, C., Reinoso, H., Cohen, A., Luna, C., Tommasino, E., Castillo, C., Bottini, R., 2010. Exogenous ABA increases yield in field-grown wheat with moderate water restriction. J. Plant Growth Regul. 29, 366-374. https://doi.org/10.1007/s00344-010-9147-y

Tworkoski, T., Wisniewski, M., Artlip, T., 2011. Application of BABA and s-ABA for drought resistance in apple. J. Appl. Hortic. 13, 85-90.

Tworkoski, T.J., Michael Glenn, D., Puterka, G.J., 2002. Response of bean to applications of hydrophobic mineral particles. Can. J. Plant Sci. 82, 217-219. https://doi.org/10.4141/p01-008

Ulameer, O.Q.A., Ahmed, S.A.A.H., 2018. Anti-transpirant role in improving the morphological growth traits of maize plants subjected to water stress! Res. Crop. 19, 593-603. https://doi.org/10.31830/2348-7542.2018.0001.35

United Nations, 2017. World population projected to reach 9.8 billion in 2050, and 11.2 billion in 2100. Dep. Econ. Soc. Aff. News, 21 June 2017. https://doi.org/10.4135/9781452234311.n318

Vaio, C. Di, Marallo, N., Lorenzo, R. Di, Pisciotta, A., 2019. Anti-Transpirant Effects on Vine Physiology, Berry and Wine Composition of cv . Aglianico ( Vitis vinifera L .) Grown in South Italy. Agronomy 9, 1-16. https://doi.org/10.3390/agronomy9050244

Vatandoost, S., Davarynejad, G., Tehranifar, A., 2017. Impact of kaolin particle film on light extinction coefficient and radiation use efficiency of pistachio ( Pistachia vera ). AgroLife Sci. J. 6, 214-218.

Wang, J., Xia, H., Lin, L.J., He, H., Liang, D., Lv, X.L., 2016. Exogenous abscisic acid increases resistances against abiotic stress and improve fruit quality of grape. J. Anim. Plant Sci. 26, 1-13.

Wang, Yanping, Wang, Ya, Ji, K., Dai, S., Hu, Y., Sun, L., Li, Q., Chen, P., Sun, Y., Duan, C., Wu, Y., Luo, H., Zhang, D., Guo, Y., Leng, P., 2013. The role of abscisic acid in regulating cucumber fruit development and ripening and its transcriptional regulation. Plant Physiol. Biochem. 64, 70-79. 
Waterland, N.L., Campbell, C.A., Finer, J.J., Jones, M.L., 2010a. Abscisic acid application enhances drought stress tolerance in bedding plants. HortScience 45, 409-413. https://doi.org/10.21273/hortsci.45.3.409

Waterland, N.L., Finer, J.J., Jones, M.L., 2010b. Benzyladenine and gibberellic acid application prevents abscisic acid-induced leaf chlorosis in pansy and Viola. HortScience 45, 925-933.

Waterland, N.L., Finer, J.J., Jones, M.L., 2010c. Abscisic acid applications decrease stomatal conductance and delay wilting in drought-stressed chrysanthemums. Horttechnology 20, 896-901.

Weaver, G.M., van lersel, M.W., 2014. Antitranspirational efficacy and longevity of abscisic acid and a synthetic abscisic acid analog in pansies (viola xwittrockiana). HortScience 49, 779-784. https://doi.org/10.21273/hortsci.49.6.779

Weerakkody, P., Jobling, J., Infante, M.M.., Rogers, G., 2010. The effect of maturity, sunburn and the application of sunscreens on the internal and external qualities of pomegranate fruit grown in Australia Scientia Horticulturae The effect of maturity, sunburn and the application of sunscreens on the internal and. https://doi.org/10.1016/j.scienta.2009.12.003

Weerasinghe, M.M., Kettlewell, P.S., Grove, I.G., Hare, M.C., 2016. Evidence for improved pollen viability as the mechanism for filmantitranspirant mitigation of drought damage to wheat yield. Crop Pasture Sci. 67, 137-146. https://doi.org/10.1071/CP15356

Wheeler, S., Loveys, B., Ford, C., Davies, C., 2009. The relationship between the expression of abscisic acid biosynthesis genes, accumulation of abscisic acid and the promotion of Vitis vinifera L. berry ripening by abscisic acid. Aust. J. Grape Wine Res. 15, 195-204. https://doi.org/10.1111/j.17550238.2008.00045.x

Williamson, R.E., 1963. The Effect of a Transpiration-Suppressant on Tobacco Leaf Temperature. Soil Sci. Soc. Am. J. 27, pp.106-106.

Woolley, J.T., 1967. Relative Permeabilities of Plastic Films to Water and Carbon Dioxide. Plant Physiol. 42, 641-643. https://doi.org/10.1104/pp.42.5.641

Xu, Z., Jiang, Y., Jia, B., Zhou, G., 2016. Elevated-CO2 response of stomata and its dependence on environmental factors. Front. Plant Sci. 7, 1-15. https://doi.org/10.3389/fpls.2016.00657

Xudan, X., 1986. The effect of foliar application of fulvic acid on water use, nutrient uptake and yield in wheat. Aust. J. Agric. Res. 37, 343-350. https://doi.org/10.1071/AR9860343

Yamamoto, L.Y., Koyama, R., De Assis, A.M., Borges, W.F.S., De Oliveira, I.R., Roberto, S.R., 2015. Color of berry and juice of "Isabel" grape treated with abscisic acid in different ripening stages. Pesqui. Agropecu. Bras. 50, 11601167. https://doi.org/10.1590/S0100-204X2015001200005

Yang, H., Li, H., Rao, L. qun, Long, G. you, Shi, G. rong, Peng, G. ping, 2011. Effects of exogenous $A B A$ on antioxidant enzymes in detached citrus leaves 
treated by rapid freezing. African J. Biotechnol. 10, 9779-9785.

Yang, W., Guo, S., Li, P., Yu, J., 2018. Foliar antitranspirant and soil superabsorbent hydrogel affect photosynthetic gas exchange and water use efficiency of maize grown under low rainfall conditions. J. Sci. Food Agric. 99, 350-359. https://doi.org/10.1002/jsfa.9195

Yee, W.L., 2012. Behavioural responses by Rhagoletis indifferens (Dipt., Tephritidae) to sweet cherry treated with kaolin- and limestone-based products. J. Appl. Entomol. 136, 124-132. https://doi.org/10.1111/j.14390418.2010.01603.x

Yu, J., Ge, H., Wang, X., Tang, R., Wang, Y., Zhao, F., Lan, W., Luan, S., Yang, L., 2017. Overexpression of Pyrabactin Resistance-Like Abscisic Acid Receptors Enhances Drought, Osmotic, and Cold Tolerance in Transgenic Poplars. Front. Plant Sci. 8, 1-13. https://doi.org/10.3389/fpls.2017.01752

Zadoks, J., Chang, T., Konzak, C., 1974. A decimal growth code for the growth stages of cereals. Weed Res. 14, 415-421.

Zhang, Xiaoyu, Zhang, Xiying, Liu, X., Shao, L., Sun, H., Chen, S., 2016. Improving Winter Wheat Performance by Foliar Spray of ABA and FA Under Water Deficit Conditions. J. Plant Growth Regul. 35, 83-96. https://doi.org/10.1007/s00344-015-9509-6

Zhang, Y., Dami, I., 2012. Improving freezing tolerance of "chambourcin" grapevines with exogenous abscisic acid. HortScience 47, 1750-1757. https://doi.org/10.21273/hortsci.47.12.1750

Zhang, Y., Mechlin, T., Dami, I., 2011. Foliar application of abscisic acid induces dormancy responses in greenhouse-grown grapevines. HortScience 46, 1271-1277. https://doi.org/10.21273/hortsci.46.9.1271

Zhimang, G., Xiaorong, W., Xueyuan, G., Jing, C., Liansheng, W., Lemei, D., Yijun, C., 2001. Effects of fulvic acid on the bioavailability of rare earth elements and GOT enzyme activity in wheat (Triticum aestivum). Chemosphere 44, 545-551. https://doi.org/10.1016/S0045-6535(00)00484-7

Zhong, Y., Ciafre, C., 2011. Role of ABA in ethylene-independent Iris flower senescence. Food Eng. 9, 261-266. 